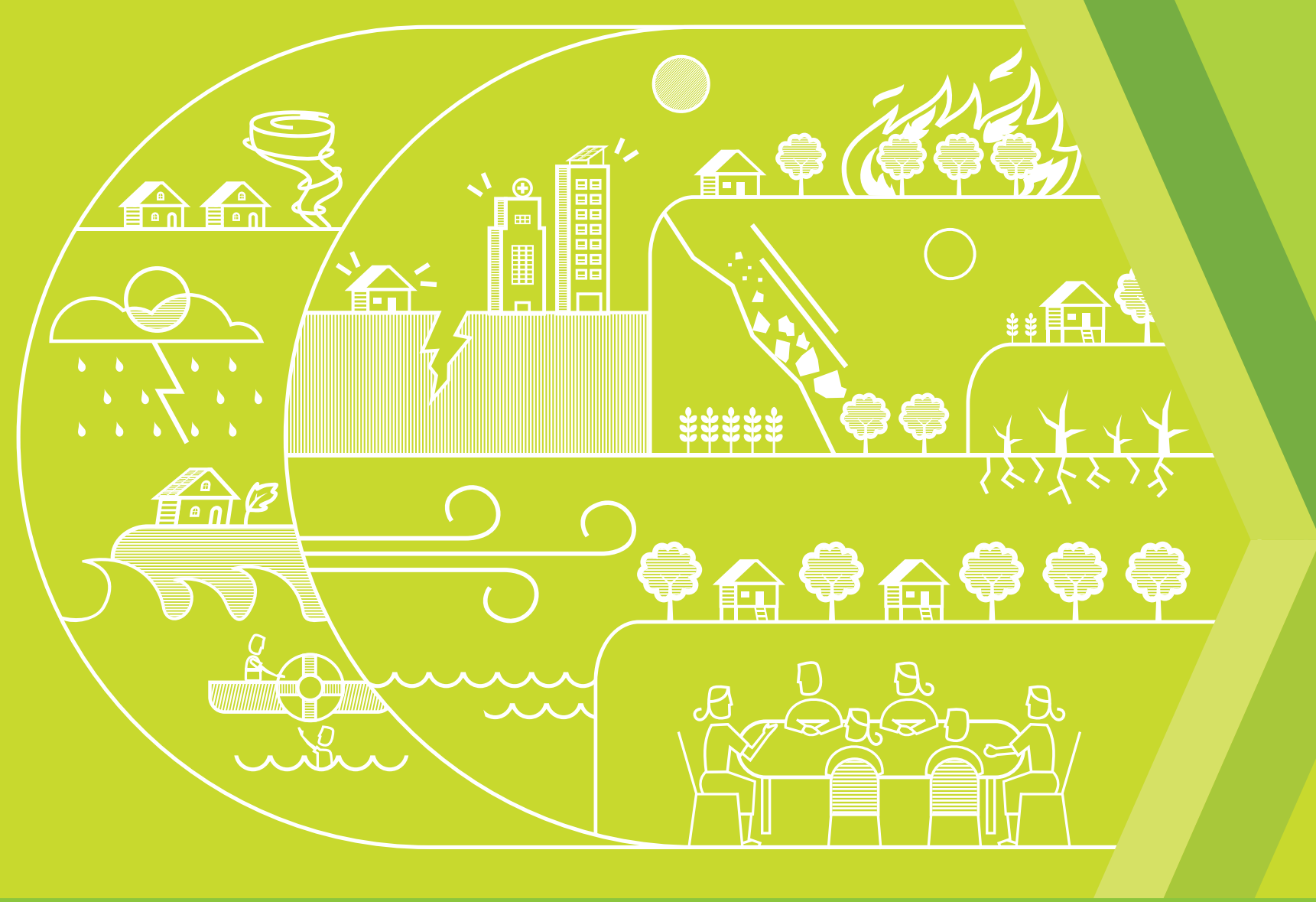

\title{
DISASTER RISK MANAGEMENT AND COUNTRY PARTNERSHIP STRATEGIES
}

\section{A Practical Guide}





\section{DISASTER RISK MANAGEMENT AND COUNTRY PARTNERSHIP STRATEGIES}

A Practical Guide

NOVEMBER 2017 


\author{
(c) 2017 Asian Development Bank \\ 6 ADB Avenue, Mandaluyong City, 1550 Metro Manila, Philippines \\ Tel +632632 4444; Fax +6326362444 \\ www.adb.org \\ Some rights reserved. Published in 2017. \\ ISBN 978-92-9261-010-4 (Print), 978-92-9261-011-1 (PDF) \\ Publication Stock No. TIM178691-2 \\ DOI: http://dx.doi.org/10.22617/TIM178691-2
}

The views expressed in this publication are those of the authors and do not necessarily reflect the views and policies of the Asian Development Bank (ADB) or its Board of Governors or the governments they represent.

ADB does not guarantee the accuracy of the data included in this publication and accepts no responsibility for any consequence of their use. The mention of specific companies or products of manufacturers does not imply that they are endorsed or recommended by ADB in preference to others of a similar nature that are not mentioned.

By making any designation of or reference to a particular territory or geographic area, or by using the term "country" in this document, $\mathrm{ADB}$ does not intend to make any judgments as to the legal or other status of any territory or area.

This work is available under the Creative Commons Attribution 3.0 IGO license (CC BY 3.0 IGO)

https://creativecommons.org/licenses/by/3.0/igo/. By using the content of this publication, you agree to be bound by the terms of this license. For attribution, translations, adaptations, and permissions, please read the provisions and terms of use at https://www.adb.org/terms-use\#openaccess

This CC license does not apply to non-ADB copyright materials in this publication. If the material is attributed to another source, please contact the copyright owner or publisher of that source for permission to reproduce it. ADB cannot be held liable for any claims that arise as a result of your use of the material.

Please contact pubsmarketing@adb.org if you have questions or comments with respect to content, or if you wish to obtain copyright permission for your intended use that does not fall within these terms, or for permission to use the ADB logo.

Notes:

In this publication, "\$” refers to US dollars.

Corrigenda to ADB publications may be found at http://www.adb.org/publications/corrigenda 


\section{Contents}

Acknowledgments

Abbreviations $v$

Executive Summary vi vi vi vis

$1 \quad$ Introduction $\quad 1$

A. Disaster Profile and Trends in Asia and the Pacific

B. Disaster Risks and Development in Asia and the Pacific

C. Disaster Risk Management at ADB

2 Scope of a National Disaster Risk Management Assessment

5
A. Objectives
B. Determining the National Disaster Risk Profile
C. Implications for Socioeconomic Development and Performance
D. Disaster Risk Management Institutional Arrangements, Policies, and Plans
E. Disaster Risk Management Practice: Key Disaster Risk Instruments and Processes
F. Sector Analysis
G. Engagement of ADB and Other Development Partners in Disaster Risk Management
$\mathrm{H}$. Conclusions of the Disaster Risk Management Assessment: Opportunities in Advance Disaster Resilience

\section{Disaster Risk Management and Country Partnership Strategies}
A. Potential Disaster Risk Management Entry Points in Country Partnership Strategy Preparation
B. Inclusive and Sustainable Growth Assessment
C. Disaster Risk Management in the Development Coordination Matrix
D. Succeeding Country Partnership Strategies
E. Monitoring

Glossary

1. Average Annual Multihazard Losses for ADB Developing Member Countries

2. Sample Terms of Reference: Disaster Risk Management Country Assessment Specialist

3. Natural Hazard Data

4. Open Spatial Data Sources on Population and Assets 37

5. Vulnerability Information $\quad 39$

6. Disaster Event and Risk Databases

7. Information on Country Disaster Risk Management Policy, Institutional Arrangements, and Capacity

8. Sample Entry Points for Integrating Disaster Risk Management into Key Sectors

9. Sample Entry Points for Disaster Risk Management in the Country Partnership Strategy Results Framework 


\section{Acknowledgments}

This document was prepared under the regional technical assistance project Development of Guidance Materials and Screening Tools for Incorporating Disaster Risk Concerns in Country Partnership Strategy and Project Preparation (TA 8752-REG) of the Asian Development Bank (ADB). The project was implemented under the overall guidance of Charlotte Benson, principal disaster risk management specialist, Sustainable Development and Climate Change Department (SDCC). This document was prepared by Alexandra Galperin (consultant).

The document benefited significantly from comments received from the following ADB staff: Maria Pia Ancora, climate change specialist, East Asia Department (EARD); Eduardo Banzon, principal health specialist, SDCC; Claudia Buentjen, principal public management specialist, SDCC; Jin Cyhn, former principal economist, Southeast Asia Department (SERD); Mary Jane David, senior public management officer (Disaster Risk Management), SDCC; Edimon Ginting, Director, economic research and regional cooperation department; Naresh Giri, senior project officer (Infrastructure), South Asia Department (SARD); Valerie Hill, director, Strategy, Policy, and Review Department (SPD); Erik Kjaergaard, disaster risk management specialist, SARD; David Daniel Oldfield, senior economist, Central and West Asia Department (CWRD); Rabindra Osti, water resources specialist, EARD; Anil Pokhrel, former disaster risk management specialist, SDCC; Nathan Rive, climate change specialist, CWRD; Arghya Sinha Roy, senior disaster risk management specialist, SDCC; Ancha Srinivasan, principal climate change specialist, SERD; Kenji Takamiya, principal planning and policy economist, SPD; and Liping Zheng, advisor, SARD.

Early external consultations were held with Sergio Lacambra, Inter-American Development Bank; Robert Reid, Global Facility for Disaster Reduction and Recovery; and Margret Arnold and Yolanta KryspinWatson, World Bank.

Grendel Saldevar-Perez, senior operations assistant, SDCC, skillfully managed budgetary and contractual matters and provided invaluable administrative support. The document was proofread by Ricardo Chan and Kae Sugawara and the layout designed by Rocilyn Locsin Laccay. 


\section{Abbreviations}

$\begin{array}{ll}\text { AAL } & \text { average annual loss } \\ \text { ADB } & \text { Asian Development Bank } \\ \text { CPS } & \text { country partnership strategy } \\ \text { DMC } & \text { developing member country } \\ \text { DRM } & \text { disaster risk management } \\ \text { FAO } & \text { Food and Agricultural Organization of the United Nations } \\ \text { GAR } & \text { Global Assessment Report on Disaster Risk Reduction } \\ \text { GDP } & \text { gross domestic product } \\ \text { GFDRR } & \text { Global Facility for Disaster Reduction and Recovery } \\ \text { IPCC } & \text { Intergovernmental Panel on Climate Change } \\ \text { SDG } & \text { Sustainable Development Goal } \\ \text { UN } & \text { United Nations } \\ \text { UNDP } & \text { United Nations Development Programme } \\ \text { UNISDR } & \text { United Nations International Strategy for Disaster Reduction }\end{array}$




\section{Executive Summary}

Disasters pose a significant threat to the sustainability of development projects and investments. At the same time, many development actions provide opportunities to strengthen disaster resilience. Reflecting this, the integration of disaster risk reduction into development forms one of three key principles of the Operational Plan for Integrated Disaster Risk Management, 2014-2020 of the Asian Development Bank $(\mathrm{ADB}){ }^{1}$

This document is intended to support the application of this principle by providing technical advice on the integration of disaster risk considerations in ADB country partnership strategy (CPS) preparation and implementation. ${ }^{2}$ The approach recognizes that disaster risk management (DRM) serves two important roles in relation to development: (i) it protects development investments and achievements from avoidable disaster damage and loss, and (ii) it promotes development strategies that increase the resilience of vulnerable communities. It is particularly relevant in the context of developing member countries that face medium and high levels of disaster risk.

The document begins by outlining the rationale for integrating DRM into development policy and practice in Asia and the Pacific. It then proceeds to outline key features of a national DRM assessment. It concludes by providing technical advice on potential DRM entry points in CPS preparation, including in the inclusive and sustainable growth assessment, and in the final CPS product.

Nine supporting appendixes are provided focusing on (i) average annual loss data (Appendix 1); (ii) sample terms of reference for a DRM assessment specialist (Appendix 2); (iii) key international and national data sources on natural hazard, exposure, vulnerability, and disaster risk (Appendixes 3-6); (iv) key data sources on government DRM policy, institutional arrangements, and capacity (Appendix 7); (v) potential entry points for integrating DRM into sector policy, capacity building, and investments (Appendix 8); and (vi) sample DRM-related outcomes and outcome indicators in the CPS results framework (Appendix 9).

The document was prepared as part of a wider capacity development technical assistance project, Development of Guidance Materials and Screening Tools for Incorporating Disaster Risk Concerns in Country Partnership Strategy and Project Preparation, financed by ADB's Technical Assistance Special Fund. ${ }^{3}$ Two companion documents focus on natural hazard data ${ }^{4}$ and on disaster risk assessment at the project level. ${ }^{5}$ The technical assistance project also supports the modification of an interactive online project climate risk screening tool-AWARE- used by ADB to integrate geological hazards, enhance weather-related hazard components, and augment screening output recommendations regarding DRM.

\footnotetext{
ADB. 2014. Operational Plan for Integrated Disaster Risk Management, 2014-2020. Manila

2 The contents presented in this documents and its companion documents do not constitute part of ADB's formal operational policies, procedures, and business processes.

3 ADB. 2014. Technical Assistance for Development of Guidance Materials and Screening Tools for Incorporating Disaster Risk Concerns in Country Partnership Strategy and Project Preparation. Manila (TA 8752-REG)

4 ADB. 2017. Natural Hazard Data: A Practical Guide. Manila.

5 ADB. 2017. Disaster Risk Assessment for Project Preparation: A Practical Guide. Manila.
} 


\section{Introduction}

\section{A. Disaster Profile and Trends in Asia and the Pacific}

Urgent action is required to strengthen disaster resilience in Asia and the Pacific. Disasters threaten sustainable socioeconomic development. They harm lives, damage infrastructure, and destroy productive capacity, with potentially significant consequences for wider economic and social aggregates such as gross domestic product (GDP), balance of payments, budget deficit, and poverty incidence. Reflecting the significance of this threat, the Sustainable Development Goals (SDGs) adopted by 193 countries at the United Nations (UN) Sustainable Development Summit in September 2015 explicitly target risk reduction under 4 of its 17 goals (UNISDR 2015). ${ }^{1}$ The developing member countries (DMCs) of the Asian Development Bank (ADB) need support in strengthening resilience as part of their efforts to achieve the SDGs and also to meet their commitments under the Sendai Framework for Disaster Risk Reduction 2015-2030, another part of the post-2015 agenda for sustainable development (UN 2015).

Despite significant advances in tropical cyclone and flood forecasting and early warning systems, overall levels of disaster-related mortality have failed to decline over the past 4 decades in Asia and the Pacific. To some degree, this can be attributed to a number of highly destructive earthquakes and tsunamis during the first decade of the new millennium (ADB 2013). Over 360,000 lives were lost as a consequence of natural hazards during 2006-2015 in Asia and the Pacific, close to levels in the 3 previous decades. About 93\% of these fatalities occurred in DMCs. Over the same period, 1.4 billion people were affected by natural hazards in the region, of which $98 \%$ were in DMCs.

Meanwhile, direct physical losses have steadily increased in recent decades both globally and in Asia and the Pacific (Figure 1). Direct physical losses totaled \$727 billion in 2006-2015 in Asia and the Pacific. ADB's DMCs alone experienced losses of $\$ 461$ billion, equivalent to an average loss of $\$ 126$ million per day. Over a longer period stretching back to 1970, growth in direct physical losses as a consequence of natural hazards in ADB's DMCs has matched growth in GDP, reflecting insufficient regard to disaster risk in either the design or location of infrastructure, homes, and other assets. With the expected rise in intensity and, in some areas, frequency of climate-related hazards as a consequence of climate change and a steadily growing concentration of people, assets, and services in hazard-prone areas, including coastal cities, growth in direct physical losses could easily overtake growth in GDP in DMCs unless urgent action is taken.

\footnotetext{
The relevant goals focus on ending poverty (Goal 1); ending hunger, achieving food security and improved nutrition, and promoting sustainable agriculture (Goal 2); making cities and human settlements inclusive, safe, resilient, and sustainable (Goal 11); and taking urgent action to combat climate change and its impacts (Goal 13).
} 
Figure 1: Direct Physical Losses as a Consequence of Natural Hazards in ADB's Developing Member Countries, 1970-2014

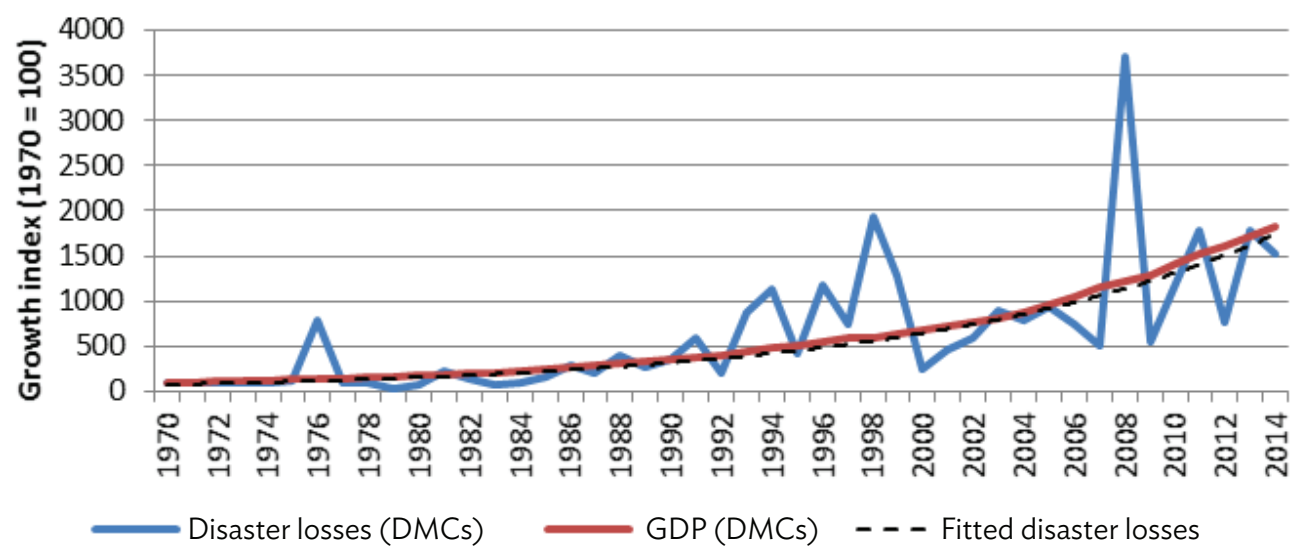

$\mathrm{ADB}=$ Asian Development Bank, $\mathrm{DMC}=$ developing member countries, $\mathrm{GDP}=$ gross domestic product Source: ADB.

Indeed, disaster losses may already be increasing in excess of GDP growth as actual losses may be higher than available data suggests. Frequent but low intensity and localized hazards (such as localized flash floods, landslides, and storms) are often underreported in national and international disasters statistics. Recent global analysis suggests that the aggregate impact of these small-scale events on agriculture, roads and most public utilities is significantly higher than that of large-scale natural hazard risks (United Nations International Strategy for Disaster Reduction [UNISDR], 2015). It is estimated that, worldwide, $98 \%$ of damage to water supply and energy, $93 \%$ of damage to agricultural crops, and $81 \%$ of damage to roads are caused by such low-intensity risk hazards. As most of these localized hazards are weather-related, their overall incidence is likely to further increase with climate change.

\section{B. Disaster Risks and Development in Asia and the Pacific}

Disaster risk is the result of the interaction of natural hazards and of the exposure of vulnerable people and assets to these potential natural hazard events. Development processes have a potentially important impact on levels of exposure of people and assets to natural hazards, and their degree of susceptibility or resilience. For instance, development often modifies existing patterns of land use, changing the exposure to natural hazards, and, possibly, vulnerability. Some development decisions have destroyed natural ecosystems that acted as a barrier against floods, storms, and landslides such as forests, wetlands, and mangroves (ADB 2013). Industrial development has often increased the number of exposed and vulnerable populations and assets in hazard-prone areas.

In Asia and the Pacific, the highest average annual losses (AALs) ${ }^{2}$ from multiple natural hazards are concentrated in larger, higher-income economies such as Japan. However, if AAL is measured relative to economic aggregates such as GDP, the value of capital stock or annual capital investment, many low- and middle-income countries have much higher levels of risk (UNISDR 2015). Indeed, disaster risk presents a serious threat to inclusive development in many of ADB's DMCs. Eleven DMCs face AALs in excess of $2 \%$ of GDP while 21 face AALs in excess of $1 \%$ of GDP. Small island developing states in the Pacific fare particularly badly (Figure 2). Countries with low levels of growth and investment find it very difficult to replace capital stock following a disaster. Lost assets and investments further hamper economic development and sustainable growth.

2 AAL is the expected loss per year calculated over a very long period, often over thousands of years. It is determined using a catastrophe model, combined with current information on assets, replacement values, and building codes to simulate possible disasters over a large number of years. 
Figure 2: Highest-Ranked Developing Member Countries According to Average Annual Loss as a Percentage of Gross Domestic Product

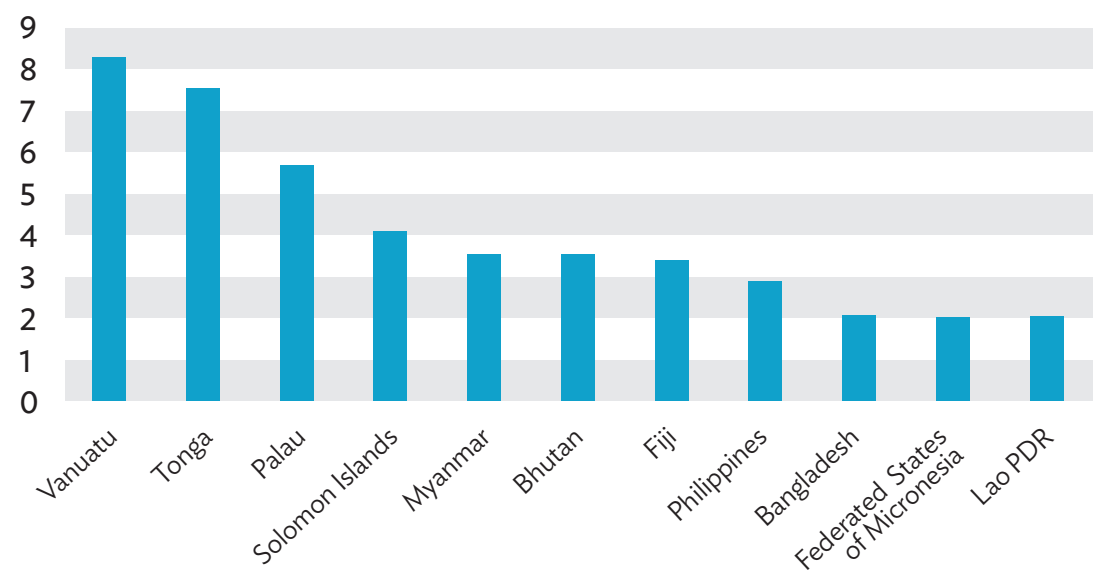

Lao PDR = Lao People's Democratic Republic.

Source: Based on data from UNISDR (2015). http://http://www.preventionweb.net/english/.

Moreover, the destructive impact of natural hazards goes well beyond direct human and physical losses. These direct losses have indirect flow consequences, disrupting livelihoods, jobs, and the provision and uptake of services such as health care, education, supply changes, and markets.

Disasters have a particularly detrimental impact on the poorest members of society, widening income and gender disparities and affecting the nutritional, health, and educational status of this group disproportionately. The poor are more likely to (i) lose places of work, homes, tools, crops, and years of schooling; and (ii) typically have highly limited access to savings, credit, or insurance to restore their assets (ADB 2013). AALs represent an important fraction of, or even exceed, annual social expenditures in many low- and middle-income countries. For instance, AAL represents $69 \%$ of annual social expenditure in the Philippines and exceeds it by a factor of two in Myanmar (UNISDR 2015).

The direct and indirect physical and social consequences of disasters can affect fundamental economic indicators such as the fiscal balance, trade balance, external reserves, national indebtedness, inflation, and GDP growth rates. It is widely observed that disasters cause significant short-term economic disruption for immediately affected communities. Longer-term impacts depend on a range of variables, but major disasters typically constitute significant economic shocks, knocking economies off course and potentially forcing them onto lower long-term growth trajectories. For example, disasters experienced in the Pacific over the period 1980-2014 reduced average trend growth in GDP from 3.3\% to 2.6\%, according to analysis by the International Monetary Fund (Cabezon et al. 2015).

Disasters can place significant pressure on public finance caused by both loss of revenue (e.g., via a decline in productivity and disruption of revenue collection) and additional spending (e.g., repair or reconstruction of public assets; relief and recovery to affected households and businesses). The capacity of government to deal with additional spending demands has important consequences for the pace and quality of recovery. Insufficient availability of timely financing for postdisaster response can result in slow and sluggish recovery, in turn exacerbating the indirect social and economic impacts of disasters, often with particularly detrimental cost to the most vulnerable and poorest segments of the population. Significant reliance on ex post funding can also mean that the impacts of a disaster continue to be felt for many years after the event. 


\section{Disaster Risk Management at ADB}

ADB's Strategy 2020 identifies disaster and emergency assistance as one of its other areas of operations, reflecting the considerable challenge that natural hazards pose to development in Asia and the Pacific (ADB 2008). The Midterm Review of Strategy 2020 reemphasized the importance of strengthened disaster resilience (ADB 2014a).

ADB's disaster risk management (DRM) approach, as outlined in its Operational Plan for Integrated Disaster Risk Management, 2014-2020, recognizes that there is nothing inevitable about the impact of a natural hazard event (ADB 2014b). Many development actions carry potential disaster risk (by increasing exposure and/or vulnerability), but also provide opportunities to strengthen resilience. There is a wide range of potential structural and nonstructural risk reduction measures that can be embedded in development investments to strengthen resilience. Actions can also be taken to enhance disaster preparedness (including financial preparedness) and response capabilities, thereby supporting more rapid recovery and so reducing the indirect and secondary consequences of direct physical damage.

To ensure that these opportunities are reaped, DRM should be integrated into government development policies and plans, as well as individual investments in hazard-prone countries. It should also be considered in development assistance, subject to discussion with the country authorities. For ADB, this may begin with the country partnership strategy (CPS). The CPS serves as the primary relationship document between a DMC and ADB (ADB 2016a). CPS preparation and implementation provide opportunities to initiate a dialogue with DMCs on DRM issues, and to factor DRM considerations into ADB assistance.

Country teams may facilitate this process by developing and maintaining national DRM assessments as part of the CPS country knowledge plan. DRM assessments can provide an understanding of levels of disaster risk, the root causes of disasters and possible consequence of climate change, the impact of disasters on the pattern and pace of socioeconomic development, and opportunities to strengthen disaster resilience. DRM assessments are recommended for countries with medium and high disaster risk, but are not mandatory.

As a broad rule of thumb, countries with AAL in excess of $2 \%$ of GDP according to the latest available global data may be considered as having a high disaster risk (Appendix 1). Those with AAL equivalent to between $0.8 \%$ and $2 \%$ of GDP may be considered medium-disaster-risk countries. However, an element of judgment is required, particularly pertaining to countries with low AALs that are nevertheless located in seismically active areas where major earthquakes periodically occur, centuries apart, causing significant loss. Geographically large countries may also contain areas with significant disaster risk and periodically high disaster losses, despite perhaps overall low AAL-to-GDP ratios (e.g., the People's Republic of China and India). It should be borne in mind that reported AALs typically exclude drought as well, so they may significantly underreport disaster risk in drought-prone countries. Moreover, AALs and disaster risk scores and rankings vary according to different assessments, reflecting factors such as selected indicators of disaster risk, model assumptions, and, where historical data are drawn on, periods of analysis, making it difficult to definitively define a list of countries with medium and high disaster risk. The Climate Change and Disaster Risk Management Division (SDCD) in the Sustainable Development and Climate Change Department (SDCC) can provide further advice pertaining to individual countries on request. 


\section{Scope of a National Disaster Risk Management Assessment}

Ideally, an analysis of disaster risk and DRM programs will form part of a government's own regular diagnostic and analytical work in disaster-prone countries, informing the determination of national development priorities and direction. In the absence of such assessments, ADB may undertake a DRM assessment directly as part of a CPS country knowledge plan.

A DRM assessment should be planned and designed in close consultation and cooperation with the government, including key sector agencies as well as national DRM agencies and ministries of finance and planning. Aspects of DRM may also be integrated into sector assessments. This section focuses primarily on stand-alone national DRM assessments, but also covers relevant questions for use in preparing sector assessments.

In most cases, it will be sufficient to base a DRM assessment on the review and collation of existing data and knowledge with the support of a consultant. ${ }^{3}$ Appendix 2 contains a sample terms of reference for a DRM country assessment consultant. The extent of existing materials should be reviewed before embarking on a DRM assessment. The Climate Change and Disaster Risk Management Division can also provide advice and guidance, and is building up a set of country reviews based on secondary material as a starting point for country teams.

A stand-alone assessment will help identify critical DRM needs in a country, and determine where and how DRM can be integrated into ADB's development portfolio (Box 1). Likewise, sector assessments can include analyses of the possible impact of disasters on sector objectives, plans, and key activities. The findings of these assessments may then be integrated into relevant ADB policy dialogue with government and into awareness-raising efforts.

\section{Box 1: Promoting Disaster Risk Management in Armenia}

The strategy section of the country partnership strategy (CPS) 2014-2018 for Armenia contains a paragraph on the provision of technical assistance and policy advice on seismic safety for public buildings, including schools. Its inclusion resulted from a stand-alone disaster risk management assessment prepared at CPS initiation, but there was no major funding for disaster risk management in ADB's project pipeline when the CPS was endorsed. Following a change of government in 2014, however, government interest grew, further motivated by a need to create jobs in the construction sector to help combat a possible economic recession. Thus, ADB received a request to support general school rehabilitation, including strengthened seismic safety. A program on seismic safety for public school buildings, the National School Strengthening and Renovation Program, was subsequently developed with ADB support targeting 377 public schools (about 20\% of all schools) over a period of 15 years. In September 2015, ADB approved an \$88.5 million investment program to support a slice of the government's School Strengthening and Renovation Program. ADB support runs for a period of 5 years from 2015 to 2020.

Source: ADB (2015b).

\footnotetext{
3 More in-depth assessments of disaster risks are covered in the companion Disaster Risk Assessment for Project Preparation: A Practical Guide (ADB 2017).
} 


\section{A. Objectives}

A DRM assessment will typically:

- determine a country's national disaster risk profile;

- analyze how disaster risks affect the country's key development objectives, macroeconomic performance, and prospects for inclusive, sustainable, and resilient growth;

- review government DRM institutional arrangements, policies, and plans;

- identify whether ADB engagement in particular development sectors could potentially increase or, conversely, offer significant opportunities to reduce disaster risk;

- review $A D B$ and other development partner engagement to date in DRM; and

- identify potential opportunities for future ADB engagement in DRM, including how ADB can add value, and potential actions to ensure that ADB's wider project portfolio is disaster resilient.

More specific objectives and outputs of a DRM assessment can be fine-tuned to a country's specific natural hazard and development context. Objectives should be clearly agreed between key stakeholders, taking into account likely information gaps.

\section{B. Determining the National Disaster Risk Profile}

A DRM assessment should begin by determining a country's disaster risk profile resulting from the interaction of key natural hazards, exposure, and vulnerability (Figure 3). These profiles should provide a qualitative and, to the degree existing data permit, quantitative overview of the scale and geographical distribution of risks from all significant natural hazards experienced by a country and the people, assets, and infrastructure most at risk, enabling the identification of key threats to sustainable development and poverty reduction.

DRM assessments will typically not entail original research on disaster risk due to funding limitations. Instead, they will collate existing data and studies. In some countries, national disaster risk assessments may have been conducted; in a majority, however, only partial information will be readily available. There is a range of national, regional, and global data sources and analytical products that can be consulted to build up a picture of disaster risk. These are presented in Appendixes 3-6.

Figure 3: Key Components of Disaster Risk

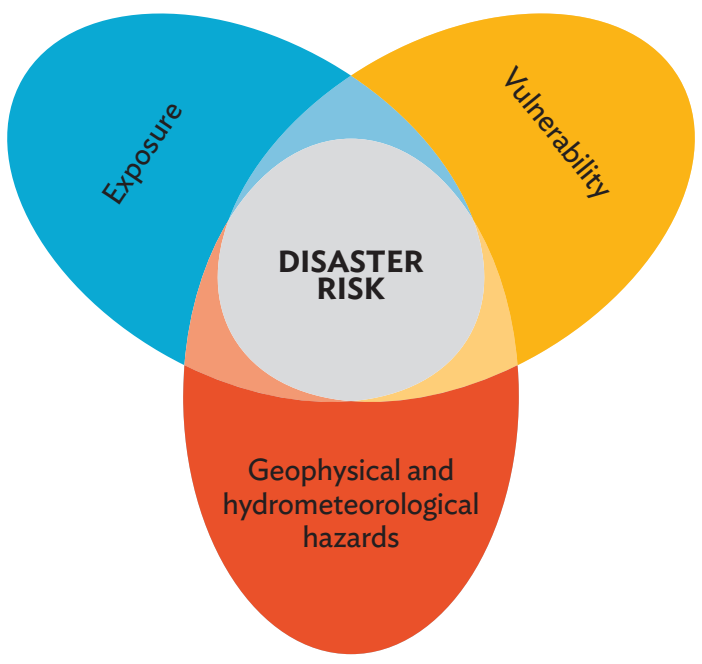

Source: ADB. 
DRM assessments should identify all significant natural hazards, their likely maximum intensity, their frequency at varying levels of intensity (i.e., of physical strength, as measured in variables such as ground shaking and wind speed), geographical distribution/location within a country, likely timing (for extreme weather events), and duration. ${ }^{4}$ In many DMCs, relevant information may be available from specialized monitoring and research agencies such as seismological and geophysical institutes or hydrometeorological offices. An overview of key sources of natural hazard data is in Appendix 3.

\section{Box 2: Natural Hazard Data (Global) Sources and Challenges}

Increasingly reliable and useful data can be accessed through a range of global natural hazard datasets. Certain key challenges often remain, however, such as the underreporting of frequent, localized natural hazards, and lack of hydrometeorological records and accurate ground elevation data to analyze floods, aggravated by uncertainty regarding the consequences of climate change for future frequency and intensity of extreme weather events.

Source: Global Facility for Disaster Reduction and Recovery (2014).

The likely consequences of climate change projections or scenarios for the frequency and intensity of weatherrelated natural hazards such as tropical cyclones, floods, storm surge, and drought should be reflected in the analysis. The analysis should consider the impacts of climate change on natural hazards both over the typical expected life of infrastructure and also over more extended periods of 50-100 years, which may raise issues regarding the longer-term structure of an economy and the detailed nature of focus and approach in specific sectors. This may involve reviewing existing analyses on potential changes in extreme weather events for a country, or accessing and analyzing projections or scenarios for relevant climate parameters (e.g., air and ocean temperature; precipitation; and the expected consequences for groundwater levels, total river flow, and sea-level rise) to assess potential changes directly. Climate change projections or scenarios are increasingly available for all countries. Potential sources of information are indicated in Appendix 3.

The DRM assessment should capture key characteristics of exposure-that is, the location and number of people, as well as location, nature, and value of assets in hazard-prone areas. Exposure can be exacerbated by inappropriate land use, such as the development of hazard-prone areas. DRM assessments are typically only expected to provide a broad overview of (i) geographical areas and populations that are highly exposed to one or more significant natural hazards, and (ii) particularly exposed economic sectors 1 here is an increasing number of open source global datasets available on population and capital stock to facilitate this, as well as analytical products such as interactive maps that contain relevant information. For data sources on exposure, see Appendix 4.

Evidence on vulnerability - that is, the propensity or predisposition of people and assets located in hazardprone areas to be adversely affected by a natural hazard event-should be reviewed from economic, social, and structural and/or physical perspectives. Damage and loss data from past disasters can provide important insights on vulnerability and disaster risk where good datasets exist and stretch back several decades. For disaster event and/or risk databases, see Appendix 6. Postdisaster damage and needs assessments undertaken in the aftermath of major disaster events can provide particularly useful insights. In many countries, however, damage and loss data are not collected in a systematic way yet, making it difficult to ascertain historical disaster impacts, particularly at a subnational level or disaggregated by sector. Further, past disasters are not sufficient predictors of future damage and loss potential given the dynamic, constantly changing scale (typically upward) and nature of disaster risk due to factors such as climate change, migration, and urbanization.

\footnotetext{
${ }_{4}$ For more details on the identification of hazards, please consult the companion Natural Hazard Data: A Practical Guide (ADB 2017).
} 
Additional information may be gleaned from secondary sector studies on vulnerability and disaster risk, where available, for example, focusing on urban infrastructure or agriculture (Box 3). Such studies can shed light on the factors underlying vulnerability and potential future changes in it, taking existing risk management mechanisms into account as well.

Box 3: Structural Vulnerability Assessments

in Armenia, Indonesia, and the Philippines

Indonesia and the Philippines have defined the vulnerability of local building stock to various key natural hazards, i.e.,- - that is, their expected performance under the physical forces of assumed natural hazard events (such as a certain level of intensity of ground shaking in an earthquake). These localized vulnerability functions will increase the accuracy of disaster risk assessments and support the design of risk reduction strategies. In Armenia, for instance, a vulnerability score was calculated for each school building based on structural typology; age; physical conditions; and the existence of buildings, structures, and objects with high vulnerability adjacent to the school. The resulting vulnerability scores, together with natural hazard and exposure scores, provided the basis for prioritizing schools for retrofitting and/or reconstruction under a National School Strengthening and Renovation Program (Box 1).

Source: Global Facility for Disaster Reduction and Recovery (2014); ADB (2015b).

Poverty is an important underlying determinant of vulnerability (section 2.B). DRM assessments can identify geographical areas within the country where poverty and significant exposure to multiple hazards overlap, and thus where particular attention may need to be paid to disaster risk in the formulation of ADB projects.

Available local or community disaster risk assessments may provide further qualitative insights; for instance, focusing on the vulnerability of informal settlements in urban environments or of rural livelihoods. Such assessments may have been undertaken, perhaps with the support of other development partners, including nongovernment organizations. These analyses may have identified particular gender, age-related, or ethnic aspects of vulnerability; impacts of disasters on access to social services such as health, education, and income; impacts of disasters on access to basic infrastructure such as clean water, sanitation, and electricity; impacts of disasters on livelihoods; and the role of land insecurity in shaping forms and levels of vulnerability. While findings from these assessments are often more indicative than conclusive, they may provide important clues on key processes that feed into vulnerability, including restricted access to services and infrastructure. For information on vulnerability, see Appendix 5. 


\section{Implications for Socioeconomic Development and Macroeconomic Performance}

A DRM assessment should include a review of evidence on the macroeconomic significance of disaster risk drawing on available historical evidence, quantitative risk assessments, and disaster scenario analysis, explored, for instance, via government forecasting models. This review helps build an understanding of the full ramifications of disaster risk and supports the prioritization of potential areas of action, including with regard to strengthened financial preparedness for disasters via instruments such as contingent disaster loans and insurance. The review should cover available evidence on aspects such as impacts on GDP and sector growth rates, trade, government expenditure and revenue, inflation, and external debt. Available data on AALs and probable maximum loss, which capture disaster risk in monetary terms, can be expressed in terms of GDP and government expenditure to provide some guide regarding the macroeconomic significance of disaster risk. In large economies, a disaggregated assessment may also be appropriate, exploring the impact and consequences of disasters on regional economies. For AALs for ADB's DMCs, see Appendix 1.

A DRM assessment should also review the extent to which DRM is mainstreamed into national development and sector plans, and the impact of past events on the achievement of related goals and targets. It should also consider the contribution of DRM to the achievement of relevant SDGs and, more generally, the potentially detrimental impact that disasters could have on SDG progress. ${ }^{5}$

Data on post disaster relief, early recovery, and reconstruction costs, including information on how this expenditure was funded and the timeliness of funding availability, should be drawn together to inform the analysis of the development and economic impacts of disasters.

\section{Disaster Risk Management Institutional Arrangements, Policies, and Plans}

DRM is a multisector responsibility and depends on an effective system of planning, coordination, regulation, implementation, and monitoring, covering all aspects of DRM from disaster risk reduction through to preparedness and response. National systems and institutions develop DRM policies and plans; guide the procedures for declaration of emergencies; lead national, local, and sector efforts to integrate DRM into development; and respond to disasters. Through the design and implementation of disaster risk financing strategies and instruments, they also help strengthen financial preparedness for potential disaster events and, thus, for timely response efforts.

A DRM assessment should identify the key characteristics of these normative systems, including strengths and weaknesses in relation to the types and levels of disaster risks that the country faces. Most important, it should identify the overall focus of existing DRM policy arrangements-that is, do they prioritize emergency management or take a more holistic approach, addressing disaster risk reduction and its integration into development as well? Table 1 provides key areas and components that DRM assessments should examine. Appendix 7 indicates potential sources of country-specific information on these and other institutional and policy-related issues.

\footnotetext{
5 The SDGs include disaster risk reduction targets under goals 1 (ending poverty); 2 (ending hunger, achieving food security and improved nutrition, and promoting sustainable agriculture); 11 (making cities and human settlements inclusive, safe, resilient, and sustainable); and 13 (taking urgent action to combat climate change and its impacts).
} 
Table 1: Key Areas of a National Disaster Risk Management Framework

\begin{tabular}{|c|c|}
\hline Key Area & Components \\
\hline $\begin{array}{l}\text { DRM policy and legal } \\
\text { framework }\end{array}$ & $\begin{array}{l}\text { - DRM policies and strategic frameworks } \\
\text { - bRM legal and regulatory framework, including safety standards, } \\
\text { - DRM plans of action and budgets } \\
\text { - Disaster response and recovery plans }\end{array}$ \\
\hline $\begin{array}{l}\text { DRM operational } \\
\text { agencies }\end{array}$ & $\begin{array}{l}\text { - Mandate of lead DRM agency } \\
\text { - DRM task forces and/or permanent units in line ministries } \\
\text { - DRM institutional arrangements at local levels of government }\end{array}$ \\
\hline $\begin{array}{l}\text { DRM coordination } \\
\text { arrangements }\end{array}$ & $\begin{array}{l}\text { - Multisector coordination for DRM } \\
\text { - Multisector task force for disaster response } \\
\text { - DRM roles of individual sectors/line ministries } \\
\text { - DRM roles of private sector and civil society }\end{array}$ \\
\hline $\begin{array}{l}\text { Resources and } \\
\text { incentives for DRM }\end{array}$ & $\begin{array}{l}\text { - Regular budgets for DRM agencies and/or activities distinguishing } \\
\text { response and DRM } \\
\text { - Tax breaks, grants, or subsidized loans for DRM investments }\end{array}$ \\
\hline $\begin{array}{l}\text { DRM and development } \\
\text { planning }\end{array}$ & $\begin{array}{l}\text { - Nature and extent of integration of DRM into national } \\
\text { development plans } \\
\text { - Disaster risk screening mechanisms for development investments } \\
\text { - Key DRM programs (government, development partners) }\end{array}$ \\
\hline
\end{tabular}

\section{Monitoring and enforcement of DRM}

- Allocation of clear responsibility for monitoring and enforcement of DRM measures, including safety standards, risk-sensitive landuse planning and relevant technical codes

- Accountability mechanisms for the enforcement of standards and codes (and avoidable losses resulting from their violation)

DRM = disaster risk management.

Source: ADB.

\section{E. Disaster Risk Management Practice: Key Disaster Risk Management Instruments and Processes}

This step of a DRM assessment should examine the translation of government DRM policies, norms, and guidelines (highlighted in the previous section) into practice. It should provide an overview of key DRM instruments and processes in place to (i) analyze disaster risks; (ii) reduce current disaster risk and avoid the creation of future risk; and (iii) manage residual disaster risk, including via disaster risk financing instruments. Table 2 provides a checklist for use in assessing DRM practice. 
Table 2: Checklist for Disaster Risk Management Practice

\begin{tabular}{|c|c|c|}
\hline Key Processes & Instruments & $\begin{array}{l}\text { Status Indicators } \\
\text { (indicative sector examples) }^{\mathrm{a}}\end{array}$ \\
\hline \multirow{3}{*}{$\begin{array}{l}\text { Assessing and } \\
\text { monitoring } \\
\text { disaster risks }\end{array}$} & $\begin{array}{l}\text { Disaster damage and } \\
\text { loss database(s) }\end{array}$ & $\begin{array}{l}\text { Up-to-date national disaster loss database } \\
\text { exists covering several decades and all types of } \\
\text { natural hazard } \\
\text { - Sector-specific disaster loss database(s) }\end{array}$ \\
\hline & $\begin{array}{l}\text { Natural hazard } \\
\text { assessments }\end{array}$ & $\begin{array}{l}\text { Responsibilities for monitoring key natural } \\
\text { hazards identified } \\
\text { - Up-to-date information (including spatial and } \\
\text { temporal data) and maps exist for key natural } \\
\text { hazards (national, subnational) } \\
\text { - Functional arrangements for communicating } \\
\text { natural hazard monitoring information, } \\
\text { including key sector agencies at subnational } \\
\text { level(s) }\end{array}$ \\
\hline & Risk assessments & $\begin{array}{l}\text { - High disaster risk geographical areas, } \\
\text { sectors, and communities identified, } \\
\text { including identification of key exposures and } \\
\text { vulnerabilities } \\
\text { - Up-to-date risk assessments reports and risk } \\
\text { mapping tools } \\
\text { - Standards and procedures for risk assessments } \\
\text { exist } \\
\text { - Mechanisms to disseminate risk assessment } \\
\text { results to potential users, including sector } \\
\text { agencies and subnational actors exist }\end{array}$ \\
\hline $\begin{array}{l}\text { Reducing } \\
\text { disaster risk }\end{array}$ & $\begin{array}{l}\text { DRM elements } \\
\text { integrated into sectoral } \\
\text { strategies, development } \\
\text { plans, and programs. }\end{array}$ & $\begin{array}{l}\text { - Relevant sectoral development plans identify key } \\
\text { disaster risks and identify specific risk reduction } \\
\text { measures } \\
\text { - Effective mechanisms are in place to screen } \\
\text { investment schemes and programs against } \\
\text { disaster risk } \\
\text { - Sector development projects address disaster } \\
\text { resilience of vulnerable communities in high-risk } \\
\text { locations } \\
\text { - Allocation of adequate budgets for integrating } \\
\text { risk reduction measures into sector investments } \\
\text { - Adequate investment in stand-alone DRM } \\
\text { measures (e.g., flood control, seismic retrofitting, } \\
\text { preparedness and early warning) } \\
\text { - Indicators established for measuring the } \\
\text { effectiveness of DRM measures in national and } \\
\text { sector development plans and programs }\end{array}$ \\
\hline
\end{tabular}




\begin{tabular}{|c|c|c|}
\hline Key Processes & Instruments & $\begin{array}{l}\text { Status Indicators } \\
\text { (indicative sector examples) }^{a}\end{array}$ \\
\hline \multirow{2}{*}{$\begin{array}{l}\text { Reducing } \\
\text { disaster risk }\end{array}$} & $\begin{array}{l}\text { Relevant sectors apply } \\
\text { key technologies and } \\
\text { strategies to reduce risks }\end{array}$ & $\begin{array}{l}\text { - Relevant technologies and good practices (e.g., } \\
\text { soil and water conservation, flood proofing) } \\
\text { captured and disseminated within sector(s) } \\
\text { Disaster-resilient technical design standards for } \\
\text { different types of infrastructure codified and } \\
\text { applied } \\
\text { - Redundancies in critical infrastructure help } \\
\text { ensure continued provision of service when } \\
\text { segments are damaged by disasters }\end{array}$ \\
\hline & $\begin{array}{l}\text { Appropriate } \\
\text { maintenance of public } \\
\text { infrastructure }\end{array}$ & $\begin{array}{l}\text { - Functional mechanisms and adequate budgets } \\
\text { exist to maintain disaster risk reduction } \\
\text { infrastructure (such as drainage and irrigation } \\
\text { channels, dams and embankments) } \\
\text { - Functional mechanisms and adequate } \\
\text { budgets exist to maintain relevant key } \\
\text { public infrastructure (roads, drainage, water, } \\
\text { communication, electricity, public buildings, } \\
\text { etc.) }\end{array}$ \\
\hline \multirow[t]{2}{*}{$\begin{array}{l}\text { Managing } \\
\text { residual risk }\end{array}$} & $\begin{array}{l}\text { Preparedness plans and } \\
\text { alert schemes }\end{array}$ & $\begin{array}{l}\text { - Effective and updated preparedness plans } \\
\text { (national/subnational/key sectors) } \\
\text { - Emergency communication and mobilization } \\
\text { systems in place (using resilient, back-up } \\
\text { technology) } \\
\text { - Regular drills, exercises, and simulations to test } \\
\text { and strengthen preparedness arrangements, } \\
\text { including early warning, alert systems, evacuation } \\
\text { management, resource mobilization and } \\
\text { coordination, and specific skills (e.g., search and } \\
\text { rescue, triage procedures) }\end{array}$ \\
\hline & $\begin{array}{l}\text { Early warning systems } \\
\text { (EWS) }\end{array}$ & $\begin{array}{l}\text { - Relevant natural hazards are monitored } \\
\text { - Responsibilities of various agencies for EWS } \\
\text { identified and agencies sufficiently equipped and } \\
\text { trained } \\
\text { - Functional arrangements to issue and disseminate } \\
\text { impact-based early warning messages, reaching } \\
\text { down to community level, in place and tested }\end{array}$ \\
\hline
\end{tabular}




\begin{tabular}{|c|c|c|}
\hline Key Processes & Instruments & $\begin{array}{l}\text { Status Indicators } \\
\text { (indicative sector examples) }^{a}\end{array}$ \\
\hline \multirow{3}{*}{$\begin{array}{l}\text { Managing } \\
\text { residual risk }\end{array}$} & Response mechanisms & $\begin{array}{l}\text { - Evacuation routes, safe areas and facilities to } \\
\text { protect lives and livelihood assets mapped, sign- } \\
\text { posted, and communicated to communities } \\
\text { - Specialized (cross-sector and sector-specific) } \\
\text { teams set up and trained (covering search and } \\
\text { rescue and medical teams, needs assessment, } \\
\text { emergency repair teams, etc.) } \\
\text { - Arrangements to mobilize relief items in place } \\
\text { - Logistical arrangements in place (transport, fuel, } \\
\text { etc.) } \\
\text { - Community-based first response capacity } \\
\text { established }\end{array}$ \\
\hline & $\begin{array}{l}\text { Damage and } \\
\text { loss assessment } \\
\text { methodology and } \\
\text { procedures }\end{array}$ & $\begin{array}{l}\text { - Robust, nationally applied damage, loss, and } \\
\text { needs assessment methodology in place } \\
\text { - Relevant (cross-sector and sector-specific) } \\
\text { trained damage and loss assessment teams exist } \\
\text { with clear criteria for their deployment } \\
\text { - Centralized reporting templates and system in } \\
\text { place } \\
\text { - Up-to-date damage and loss database } \\
\text { maintained, covering both major and minor events }\end{array}$ \\
\hline & Disaster risk financing & $\begin{array}{l}\text { - Government's explicit and implicit contingent } \\
\text { liability for disaster relief, early recovery, and } \\
\text { reconstruction estimated and disclosed } \\
\text { - Comprehensive disaster risk financing strategy in } \\
\text { place } \\
\text { - Sovereign ex ante (e.g., contingency budget lines, } \\
\text { contingency reserves, contingent credit, and } \\
\text { insurance) disaster risk financing instruments in } \\
\text { place } \\
\text { - Private sector and household disaster insurance } \\
\text { cover, including crop insurance and micro } \\
\text { insurance, available }\end{array}$ \\
\hline
\end{tabular}




\begin{tabular}{|c|c|c|}
\hline Key Processes & Instruments & $\begin{array}{c}\text { Status Indicators } \\
\text { (indicative sector examples) }^{a}\end{array}$ \\
\hline $\begin{array}{l}\text { Managing } \\
\text { residual risk }\end{array}$ & Recovery & $\begin{array}{l}\text { - Effective arrangements for quick recovery of } \\
\text { essential services and critical infrastructure in } \\
\text { place } \\
\text { - Clear criteria and standards exist for "building } \\
\text { back better" in key sectors } \\
\text { - Mechanisms and cross-sector responsibilities } \\
\text { defined for design and execution of an integrated } \\
\text { recovery plan } \\
\text { - Support for livelihood recovery with a focus on } \\
\text { vulnerable groups }\end{array}$ \\
\hline
\end{tabular}

DRM = disaster risk management.

a These instruments, indicators, and sector examples are indicative, i.e., depending on the country's natural hazard and risk profile as well as its priority DRM needs, the portfolio of ADB DRM assessments may focus on selected instruments and core indicators. $b$ Relevant to ADB's key sectors of engagement in a country.

c E.g., poorly maintained infrastructure, such as drainage or irrigation systems, can increase both exposure and vulnerability of communities to floods or drought. Lack of maintenance of public buildings affects structural and nonstructural vulnerability (e.g., nonfixed cracks, blocked evacuation routes).

Source: ADB.

\section{F. Sector Analysis}

To inform ADB's strategic programming, a DRM assessment may also examine key development sectors as per ADB's current and likely future project portfolio and review both their vulnerability to natural hazards and potential opportunities for strengthening resilience. Sectors such as agriculture, energy, transport, and water and other urban infrastructure and services may potentially suffer high disaster losses, but these losses could be significantly reduced if DRM is systematically integrated into sector policy and practice.

A good starting point for sector-specific DRM analysis is a review of the historical or potential impact of disasters on the sector, and of existing and required DRM capacities (Figure 4). This requires an understanding of whether and how sector activities have exacerbated disaster risk in the past. It also requires an understanding and careful cross-sector analysis of the impact of actions in other sectors (e.g., water) on disaster risk in the sector under review (e.g., agriculture) and vice versa.

\section{Figure 4: Key Development Sectors and Disaster Risk Management: Basic Questions}
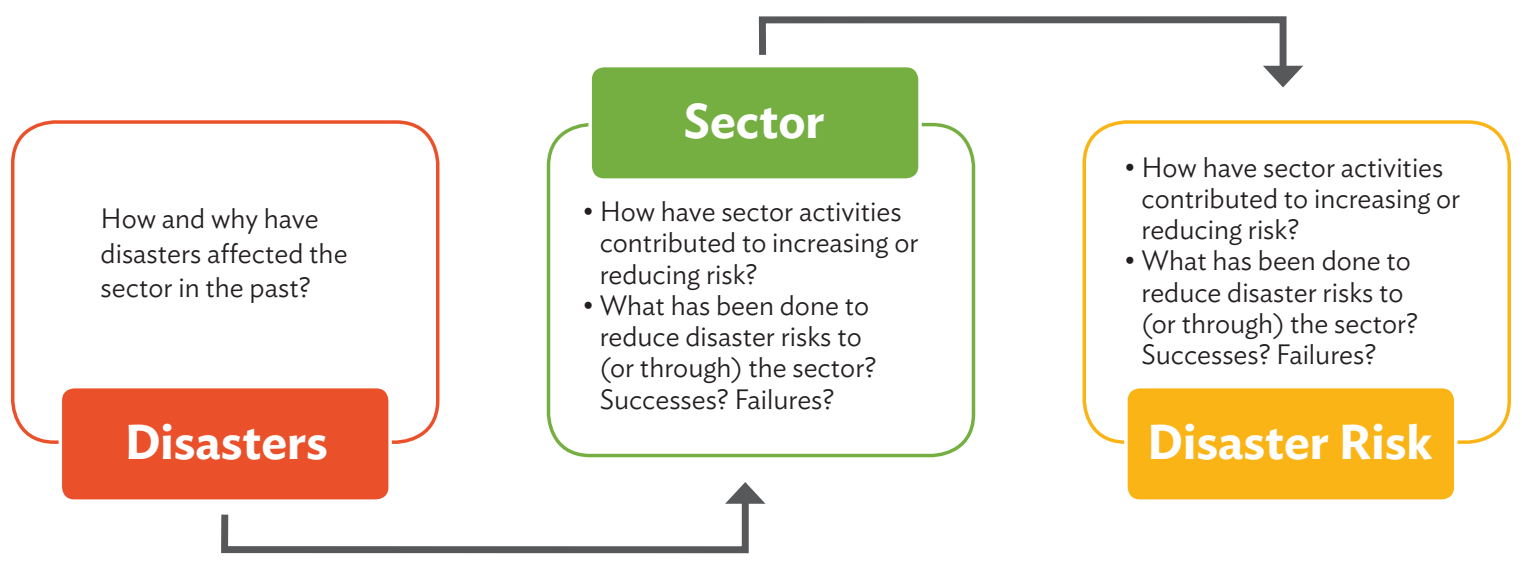

Source: ADB. 
Table 3 provides some illustrative examples of the potential impact of disasters on key sectors, how sector activities (or investments) could potentially exacerbate disaster risk, and sector-specific opportunities to address disaster risk. For a more comprehensive list of sector-specific DRM options, see also Appendix 8. The examples in Table 3 are indicative, rather than exhaustive, and individual sectors have only been analyzed against a single type of natural hazard. A real analysis would take a multi-hazard approach, examining the disaster risks associated with all relevant natural hazards.

Table 3: Analyzing Disaster Risk Management in Relation to Sectors: Illustrative Examples

\begin{tabular}{|c|c|c|c|}
\hline Sector & $\begin{array}{l}\text { Potential Disaster } \\
\text { Impact }\end{array}$ & $\begin{array}{l}\text { Potential Adverse } \\
\text { Impact of Sector } \\
\text { Activities on } \\
\text { Disaster Risk }\end{array}$ & $\begin{array}{c}\text { Opportunities for } \\
\text { Strengthened Disaster } \\
\text { Resilience }\end{array}$ \\
\hline $\begin{array}{l}\text { Agriculture } \\
\text { and Natural } \\
\text { Resources } \\
\text { (Example: Floods) }\end{array}$ & $\begin{array}{l}\text { Damage: e.g., crops, } \\
\text { livestock, fisheries, } \\
\text { plantations; ecosystems; } \\
\text { agricultural tools; rural } \\
\text { irrigation, drainage, } \\
\text { and flood protection } \\
\text { infrastructure; on-farm } \\
\text { storage; animal shelters; } \\
\text { rural market infrastructure; } \\
\text { agroprocessing } \\
\text { infrastructure; and seed } \\
\text { supply. } \\
\text { Losses: } \\
\text { - Output and } \\
\text { productivity: lower } \\
\text { outputs due to } \\
\text { interrupted agricultural } \\
\text { activity and yield } \\
\text { declines; interrupted } \\
\text { supply chains } \\
\text { - Impact on } \\
\text { poverty: enhanced } \\
\text { indebtedness due } \\
\text { to inability to repay } \\
\text { agricultural loans; } \\
\text { extended impact on } \\
\text { livelihoods where } \\
\text { recovery takes multiple } \\
\text { seasons and/or years } \\
\text { - Macroeconomic } \\
\text { impact: consequences } \\
\text { for sector GDP, } \\
\text { exports, imports, } \\
\text { inflation, etc. }\end{array}$ & $\begin{array}{l}\text { - Expansion of } \\
\text { agricultural activities } \\
\text { causes the loss } \\
\text { of protective } \\
\text { ecosystems } \\
\text { - Unsustainable } \\
\text { agricultural practices } \\
\text { cause soil erosion } \\
\text { and sedimentation of } \\
\text { waterways } \\
\text { - Poorly constructed } \\
\text { rural drainage } \\
\text { systems and } \\
\text { abandoned, clogged } \\
\text { irrigation channels } \\
\text { - Promotion of high- } \\
\text { yielding crops with } \\
\text { limited attention } \\
\text { to natural hazard } \\
\text { resilience } \\
\text { Extreme poverty of } \\
\text { small farmers leads } \\
\text { to overexploitation of } \\
\text { natural resources }\end{array}$ & $\begin{array}{l}\text { - Strengthen research } \\
\text { on hazard-resilient } \\
\text { crops and varieties and } \\
\text { their availability and } \\
\text { associated crop advice } \\
\text { - Advocacy to encourage } \\
\text { pricing, subsidy, and tax } \\
\text { policies that favor more } \\
\text { sustainable agricultural } \\
\text { practices } \\
\text { - Promote mixed } \\
\text { cropping systems that } \\
\text { (i) spread small farmers' } \\
\text { risks of losses, and } \\
\text { (ii) minimize negative } \\
\text { environmental impact } \\
\text { - Promote public-private } \\
\text { partnerships for weather } \\
\text { index-based crop or } \\
\text { livestock insurance } \\
\text { - Strengthen watershed } \\
\text { management systems in } \\
\text { flood-prone river basins } \\
\text { - Strengthen seasonal } \\
\text { and short-term weather } \\
\text { forecasting and crop } \\
\text { advisory services for } \\
\text { farmers }\end{array}$ \\
\hline
\end{tabular}




\begin{tabular}{|c|c|c|c|}
\hline Sector & $\begin{array}{l}\text { Potential Disaster } \\
\text { Impact }\end{array}$ & $\begin{array}{c}\text { Potential Adverse } \\
\text { Impact of Sector } \\
\text { Activities on } \\
\text { Disaster Risk }\end{array}$ & $\begin{array}{c}\text { Opportunities for } \\
\text { Strengthened Disaster } \\
\text { Resilience }\end{array}$ \\
\hline $\begin{array}{l}\text { Transport } \\
\text { (Example: } \\
\text { Earthquakes) }\end{array}$ & $\begin{array}{l}\text { Damage: urban and } \\
\text { rural road, water, sea, rail, } \\
\text { and air transport (e.g., } \\
\text { road networks, bridges, } \\
\text { railways, transport hubs } \\
\text { such as bus and railway } \\
\text { stations, ports, cargo } \\
\text { services and fleets, } \\
\text { workshops, and repair } \\
\text { facilities) } \\
\text { Losses: } \\
\text { - Output and } \\
\text { productivity: reduced } \\
\text { revenue flows from } \\
\text { transport; additional } \\
\text { costs of alternative } \\
\text { transport modes and/ } \\
\text { or routes; restricted } \\
\text { movement of goods } \\
\text { and services, with } \\
\text { consequences } \\
\text { for processing } \\
\text { (particularly just-in- } \\
\text { time supply chains) } \\
\text { and commerce } \\
\text { Impact on poverty: } \\
\text { reduced mobility, } \\
\text { impacting livelihood } \\
\text { opportunities for the } \\
\text { poor } \\
\text { Macroeconomic } \\
\text { impact: } \\
\text { consequences for } \\
\text { sector GDP, exports, } \\
\text { imports, inflation, } \\
\text { etc. }\end{array}$ & $\begin{array}{l}\text { - Strong dependence } \\
\text { on a few major } \\
\text { highways with limited } \\
\text { redundancies } \\
\text { - Road networks are } \\
\text { regularly congested } \\
\text { - Design of highway } \\
\text { network has mostly } \\
\text { ignored seismic risk } \\
\text { - Road maintenance } \\
\text { is inadequate, } \\
\text { exacerbating } \\
\text { structural } \\
\text { weaknesses } \\
\text { - Bridges are } \\
\text { structurally unsafe } \\
\text { in the event of } \\
\text { earthquakes } \\
\text { - Sector has a very low } \\
\text { response capacity; } \\
\text { e.g., there are no } \\
\text { arrangements in } \\
\text { place to mobilize } \\
\text { emergency repair } \\
\text { teams or facilitate } \\
\text { rapid access to } \\
\text { affected areas }\end{array}$ & $\begin{array}{l}\text { Collect sector-specific } \\
\text { disaster damage and } \\
\text { loss data as part of road } \\
\text { databases } \\
\text { - Develop a transport } \\
\text { master plan that takes } \\
\text { disaster risks into } \\
\text { account, including } \\
\text { the creation of } \\
\text { redundancies in the } \\
\text { road network } \\
\text { - Review technical } \\
\text { specifications for road } \\
\text { design, taking disaster } \\
\text { risk and climate change } \\
\text { into account } \\
\text { Support the design of } \\
\text { an integrated transport } \\
\text { disaster response plan } \\
\text { Strengthen response } \\
\text { capacity; e.g., strengthen } \\
\text { emergency repair teams; } \\
\text { stockpile temporary } \\
\text { bridges (e.g., pontoon } \\
\text { bridges, bailey bridges, } \\
\text { as appropriate) and } \\
\text { heavy construction } \\
\text { equipment; establish } \\
\text { prenegotiated contracts } \\
\text { with transport } \\
\text { contractors } \\
\text { Develop disaster risk } \\
\text { financing instruments } \\
\text { (e.g., insurance) } \\
\text { to support swift } \\
\text { reconstruction } \\
\text { eriations }\end{array}$ \\
\hline
\end{tabular}




\begin{tabular}{|c|c|c|c|}
\hline Sector & $\begin{array}{l}\text { Potential Disaster } \\
\text { Impact }\end{array}$ & $\begin{array}{l}\text { Potential Adverse } \\
\text { Impact of Sector } \\
\text { Activities on } \\
\text { Disaster Risk }\end{array}$ & $\begin{array}{c}\text { Opportunities for } \\
\text { Strengthened Disaster } \\
\text { Resilience }\end{array}$ \\
\hline $\begin{array}{l}\text { Energy } \\
\text { (Example: Intense } \\
\text { rainfall, landslides, } \\
\text { and floods) }\end{array}$ & $\begin{array}{l}\text { Damage: power } \\
\text { generation plants, } \\
\text { transmission and } \\
\text { distribution systems, } \\
\text { and energy distribution } \\
\text { centers and works } \\
\text { Losses: } \\
\text { - Output and } \\
\text { productivity: } \\
\text { reduced revenue } \\
\text { flows from energy, } \\
\text { additional costs of } \\
\text { alternative ways of } \\
\text { maintaining supply } \\
\text { and transmission } \\
\text { of energy, and } \\
\text { consequences for } \\
\text { productive and social } \\
\text { sector } \\
\text { - Impact on poverty: } \\
\text { possible impact } \\
\text { on employment, } \\
\text { informal livelihoods } \\
\text { and delivery of } \\
\text { essential services } \\
\text { Macroeconomic } \\
\text { impact: } \\
\text { consequences for } \\
\text { sector GDP, exports, } \\
\text { imports, inflation, } \\
\text { etc. }\end{array}$ & $\begin{array}{l}\text { - No early warning } \\
\text { system to detect high } \\
\text { sediment or floods } \\
\text { that could potentially } \\
\text { damage turbines } \\
\text { and power plant } \\
\text { structures } \\
\text { - Strong dependence } \\
\text { on a small number of } \\
\text { old, inefficient power } \\
\text { plants } \\
\text { - A recent project to } \\
\text { invest in small-scale } \\
\text { power plants and } \\
\text { transmission stations } \\
\text { ignored the flooding } \\
\text { and landslide hazard } \\
\text { - Lack of hazard- } \\
\text { resilient technical } \\
\text { design standards for } \\
\text { energy infrastructure } \\
\text { - Inadequate } \\
\text { maintenance of } \\
\text { transmission and } \\
\text { distribution lines } \\
\text { Slow postdisaster } \\
\text { recovery capacity, } \\
\text { taking months for } \\
\text { full restoration of } \\
\text { electricity supply }\end{array}$ & $\begin{array}{l}\text { - Strengthen sector- } \\
\text { specific monitoring } \\
\text { and early warning } \\
\text { mechanisms } \\
\text { - Create redundancies } \\
\text { in energy generation, } \\
\text { transmission, and } \\
\text { distribution systems } \\
\text { - Create hazard-specific } \\
\text { design standards (e.g., } \\
\text { ring distribution systems } \\
\text { instead of radial ones) } \\
\text { - Apply risk-sensitive } \\
\text { design, construction, } \\
\text { operation, and } \\
\text { maintenance standards } \\
\text { - Retrofit and upgrade } \\
\text { critical power } \\
\text { installations and assets } \\
\text { (e.g., elevate critical } \\
\text { power installations) } \\
\text { - Precontract emergency } \\
\text { repair teams } \\
\text { - Develop disaster risk } \\
\text { financing instruments } \\
\text { (e.g., insurance) to } \\
\text { finance reconstruction }\end{array}$ \\
\hline $\begin{array}{l}\text { Water and } \\
\text { other Urban } \\
\text { Infrastructure and } \\
\text { Services } \\
\text { (Example: } \\
\text { Earthquakes) }\end{array}$ & $\begin{array}{l}\text { Damage: key urban } \\
\text { infrastructure and } \\
\text { services such as urban } \\
\text { water supply, treatment } \\
\text { plants, pumping stations, } \\
\text { distribution systems, } \\
\text { sewerage facilities, } \\
\text { flood protection, solid } \\
\text { waste management, and } \\
\text { housing }\end{array}$ & $\begin{array}{l}\text { - City's master } \\
\text { plan significantly } \\
\text { underestimates } \\
\text { earthquake risk } \\
\text { - Urban infrastructure } \\
\text { mostly old and } \\
\text { dilapidated and with } \\
\text { limited redundancies } \\
\text { - A number of } \\
\text { settlements are } \\
\text { sprawling into hills } \\
\text { that are prone to } \\
\text { landslides }\end{array}$ & $\begin{array}{l}\text { - Conduct a multihazard } \\
\text { risk assessment for } \\
\text { critical systems such } \\
\text { as water supply and } \\
\text { sewerage system } \\
\text { - Develop and/or update } \\
\text { the urban master plan } \\
\text { to address disaster risk } \\
\text { - Create redundancies } \\
\text { in critical systems (e.g., } \\
\text { water supply, power, } \\
\text { communications) }\end{array}$ \\
\hline
\end{tabular}




\begin{tabular}{|c|c|c|c|}
\hline Sector & $\begin{array}{l}\text { Potential Disaster } \\
\text { Impact }\end{array}$ & $\begin{array}{l}\text { Potential Adverse } \\
\text { Impact of Sector } \\
\text { Activities on } \\
\text { Disaster Risk }\end{array}$ & $\begin{array}{c}\text { Opportunities for } \\
\text { Strengthened Disaster } \\
\text { Resilience }\end{array}$ \\
\hline $\begin{array}{l}\text { Water and } \\
\text { other Urban } \\
\text { Infrastructure and } \\
\text { Services } \\
\text { (Example: } \\
\text { Earthquakes) }\end{array}$ & $\begin{array}{l}\text { Losses: } \\
\text { - Output and } \\
\text { productivity: reduced } \\
\text { revenue flows } \\
\text { from water sector, } \\
\text { additional costs in } \\
\text { maintaining supply } \\
\text { and delivery of water, } \\
\text { and consequences } \\
\text { for water-dependent } \\
\text { productive and social } \\
\text { sectors } \\
\text { - Impact on } \\
\text { poverty: Impact } \\
\text { on employment, } \\
\text { informal livelihoods, } \\
\text { and delivery of } \\
\text { essential services } \\
\text { Macroeconomic } \\
\text { impact: } \\
\text { consequences for } \\
\text { sector GDP, exports, } \\
\text { imports, inflation, } \\
\text { etc. }\end{array}$ & & \\
\hline $\begin{array}{l}\text { Health } \\
\text { (Example: Floods) }\end{array}$ & $\begin{array}{l}\text { Damage: key health } \\
\text { infrastructure including } \\
\text { hospitals and health } \\
\text { facilities } \\
\text { Losses: } \\
\text { - Output and } \\
\text { productivity: } \\
\text { additional costs } \\
\text { of bringing in } \\
\text { emergency health- } \\
\text { care providers and } \\
\text { consequences } \\
\text { of deterioration } \\
\text { in health status } \\
\text { for economic } \\
\text { productivity } \\
\text { Impact on poverty: } \\
\text { reduced access to } \\
\text { health care and/or } \\
\text { increased user fees } \\
\text { and out-of-pocket } \\
\text { payments for health } \\
\text { services, driving } \\
\text { people (deeper) } \\
\text { into poverty and/or } \\
\text { undermining their } \\
\text { health status }\end{array}$ & $\begin{array}{l}\text { - Health facility } \\
\text { buildings located } \\
\text { and designed with } \\
\text { insufficient regard to } \\
\text { flood risk } \\
\text { - Guidelines for the } \\
\text { construction of } \\
\text { hospitals and other } \\
\text { health facilities fail } \\
\text { to take sufficient } \\
\text { account of potential } \\
\text { disaster risk } \\
\text { - Guidelines on health- } \\
\text { care management do } \\
\text { not take flood and } \\
\text { other disaster risk } \\
\text { into account (e.g., } \\
\text { radiology units are } \\
\text { placed on the ground } \\
\text { floor and generators } \\
\text { are placed in } \\
\text { basements, exposing } \\
\text { both to potential } \\
\text { flooding) } \\
\text { Inadequate } \\
\text { maintenance of } \\
\text { health-care facilities }\end{array}$ & $\begin{array}{l}\text { - Revise current } \\
\text { construction guidelines } \\
\text { for health-care } \\
\text { facilities to take } \\
\text { account of disaster } \\
\text { risk, drawing on World } \\
\text { Health Organization } \\
\text { guidelines on SAFE } \\
\text { Hospitals } \\
\text { - Integrate DRM } \\
\text { aspects into guidelines } \\
\text { on health-care } \\
\text { management } \\
\text { - Create redundancies in } \\
\text { health-care capacity } \\
\text { - Develop a sector- } \\
\text { specific DRM plan } \\
\text { - Provide DRM training } \\
\text { to health-care } \\
\text { providers and ancillary } \\
\text { staff } \\
\text { Create emergency } \\
\text { health response teams }\end{array}$ \\
\hline
\end{tabular}




\section{G. Engagement of ADB and Other Development Partners in Disaster Risk Management}

A DRM assessment should review ADB's involvement to date in DRM in the country, key challenges, and results. ${ }^{6}$ The assessment should include an assessment of the impact of past disasters on the performance of ADB's project portfolio and its role in postdisaster response, particularly in the past 10 years. The involvement of other development partners in DRM, key achievements, and future plans should also be reviewed and any key gaps identified. Lessons should be drawn to inform ADB's future engagement in DRM in the country. Potential opportunities for development partnerships and/or consortia, as illustrated in Box 4, to help motivate stronger, coordinated engagement in DRM and, if necessary, help stimulate greater government interest in the issue could be explored as well.

\section{Box 4: The Nepal Risk Reduction Consortium}

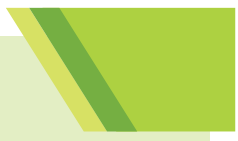

The Nepal Risk Reduction Consortium provides an interesting example of the alignment of national and international partners on disaster risk reduction according to comparative strengths and interest. Launched by the Government of Nepal in 2009, the consortium brings together a number of international humanitarian and development partners to contribute to a prioritized common set of disaster risk reduction actions in five so-called flagship areas.

\begin{tabular}{lll}
\multicolumn{1}{c}{ Flagship Program } & Coordinating Agency & \multicolumn{1}{c}{ Lead Agency } \\
$\begin{array}{lll}\text { Improved school and hospital } \\
\text { safety }\end{array}$ & $\begin{array}{l}\text { Asian Development } \\
\text { Bank and World Health } \\
\text { Organization }\end{array}$ & $\begin{array}{l}\text { Ministry of Education } \\
\text { (school safety) and Ministry } \\
\text { of Health and Population } \\
\text { (hospital safety) }\end{array}$ \\
$\begin{array}{l}\text { Enhanced emergency } \\
\text { preparedness and response } \\
\text { capacity }\end{array}$ & Red Cross Alliance & Ministry of Home Affairs \\
$\begin{array}{l}\text { Strengthened flood risk } \\
\text { management }\end{array}$ & World Bank and Global & \\
$\begin{array}{l}\text { Integrated community-based } \\
\text { disaster risk reduction }\end{array}$ & Reduction and Recovery & Ministry of Irrigation \\
$\begin{array}{l}\text { Policy and/or institutional support } \\
\text { for disaster risk management }\end{array}$ & Red Cross & Ministry of Federal Affairs \\
& Development Programme & and Local Development \\
Source: Taylor et al. (2013). & &
\end{tabular}

\footnotetext{
6 Possible sources of information are end-of-program reports, CPS final reviews and country assistance program evaluations (section 3.E for more details) and ADB's Sustainable Development and Climate Change Department's DRM database.
} 


\section{H. Conclusions of the Disaster Risk Management Assessment: Identifying Opportunities in Advance Disaster Resilience}

The final section of a DRM assessment should identify potential opportunities for ADB engagement in DRM, taking into account the country's disaster risk profile and socioeconomic significance, DRM gaps and challenges, ADB's past and likely future sector areas of focus in a particular country, its past engagement in DRM, and the likely nature and scale of engagement of other development partners in the area.

It should summarize findings regarding the past and potential future implications of disaster risk, taking potential impacts of climate change into account, for inclusive and sustainable growth in the country, with particular reference to the country's key development goals and to sectors supported by ADB. The assessment should lay out (i) whether the achievement of these objectives is potentially threatened by natural hazards, and (ii) whether and how national development objectives and initiatives in key sectors may themselves contribute to increased or reduced disaster risk. This will help reveal the degree to which DRM may need to be addressed in future CPSs.

Key gaps and areas of comparative advantage for potential ADB engagement in DRM should be determined based on an analysis of the plans and programs of the government and key development partners, and ADB's own development portfolio. While addressing priority disaster risk concerns, identified opportunities should also build on ADB's development portfolio and track record in the country. Recommendations should also be provided regarding key actions to ensure that ADB's wider project portfolio is disaster resilient. 


\section{Disaster Risk Management and Country Partnership Strategies}

\section{A. Potential Disaster Risk Management Entry Points in Country Partnership Strategy Preparation}

The CPS business processes (ADB 2015a) emphasize the importance of knowledge management and call for inclusion of the country knowledge plan. An analysis of disaster risk and its management may form part of a government's own diagnostic and analytical work in setting its national development priorities and direction. In the absence of such assessments, however, ADB may include a DRM assessment in the CPS country knowledge plan, and also incorporate DRM considerations into sector-specific assessments where relevant (section 2). For DMCs where such knowledge work has been undertaken, key findings, together potentially with inputs from the Climate Change and Disaster Risk Management Thematic Group, may feed into the inclusive and sustainable growth assessment undertaken as part of the next CPS preparation. The inclusive and sustainable growth assessment plays an important role in setting out the rationale for determining strategic objectives and thematic priorities in a CPS. Disaster risk may also be raised in the country consultations, drawing on its treatment in the national development plan, relevant lessons from the preceding CPS and recent ADB engagement in DRM (including in disaster response), and its handling in the inclusive and sustainable growth assessment and the development coordination matrix.

Integrating DRM into CPSs is easiest in DMCs where disaster risk concerns have been addressed in previous national development plans and CPSs, or where ADB's country portfolio includes a disaster response project that was requested subsequent to the finalization of the latest CPS. Experience has shown that the participation of a well-respected DRM champion who raises DRM as a relevant concern throughout the CPS formulation exercise is also very important. Such a champion may come from ADB's own ranks (a number of country directors have assumed this role), but could also be a government or civil society partner.

\section{B. Inclusive and Sustainable Growth Assessment}

In medium- and high-risk DMCs, the potential impact of natural hazards on development may justify the integration of disaster risk concerns into the inclusive and sustainable growth assessment for the next CPS. This would require an understanding of the root causes of disasters and their impact on the patterns and pace of socioeconomic development in general and a government's development priorities and prospects in particular, drawing on relevant knowledge products as discussed in section 2. It would also require appreciation of the potential consequences of particular development priorities, policies, and practice in either exacerbating or reducing disaster risk.

Findings of the completed DRM assessment that may be particularly relevant to the inclusive and sustainable growth assessment include those pertaining to:

- impact of past and potential future disasters on macroeconomic performance and indicators, e.g., on GDP, sector GDP, infrastructure development, government expenditure and revenue, trade, external debt, and inflation;

- impact of past and potential future disasters on the poor, preferably gender-disaggregated;

- impact of past and potential future disasters on the achievement of the SDGs;

- DRM capacity, including with regard to the management of residual risk and related fiscal impact, which in turn will influence the speed of postdisaster recovery, and depth and nature of the indirect consequences of direct physical damage; and

- extent of importance and nature of focus accorded to DRM in national development priorities. 
Analysis of the potential development challenges posed by disaster risk-such as volatile GDP performance, lower long-term growth trajectories, fiscal instability, and slower progress in poverty reduction and achievement of the SDGs - will require information on past and potential future disaster impacts on sector performance, assets, and communities, as well as information on the costs of response and recovery. Disaster risk may be acknowledged more directly in the inclusive and sustainable growth assessment as an environmental issue where relevant as well, also taking into account consequences of climate change and environmental degradation for the frequency and intensity of future natural hazard events.

Other relevant studies that have been conducted by the government or by other development partners in support of government DRM plans and strategies can be drawn on to inform the inclusive and sustainable growth assessment if ADB has not yet engaged in a DRM assessment. ADB's Sustainable Development and Climate Change Department is building up a set of country reviews based on secondary material as a starting point for country teams, as already noted. These reviews provide an overview of a country's disaster profile, the impact of past disasters, the institutional setup, and existing DRM capacity. They list both national and international partners in DRM and identify additional sources of information.

\section{Disaster Risk Management in the Development Coordination Matrix}

In CPSs that focus on areas of strategic and operational support of direct relevance to DRM-such as strengthening resilience, improving environmental sustainability or promoting climate change adaptation, and climate change response-development partner engagement in DRM should be captured in the development coordination matrix. The completed DRM assessment and development coordinationlinked documents for any existing DRM-related projects in the country will contain relevant information for use in constructing this matrix.

\section{Succeeding Country Partnership Strategies}

The above analysis, together with consultations and meetings conducted during the CPS preparatory process, provides a basis for determining if and how to reflect DRM considerations in the next CPS for a particular country (section 1.C).

To identify DRM actions relevant to the specific context and core development needs of individual countries, the CPS narrative may consider DRM-specific aspects in answering the four key questions that guide the overall CPS formulation process (ADB 2016a), as outlined in Table 4. 


\section{Table 4: Integrating Disaster Risk Management Considerations into}

the Country Partnership Strategy: Guiding Questions

\section{Question}

\section{DRM-specific aspects}

What are the key development challenges of a $D M C$ that $A D B$ will try to address through its involvement?

What are ADB's strategic objectives and priorities for engaging with the DMC, considering the DMC's challenges, and lessons from past engagement?

How is ADB's engagement aligned with the government's development plan and its own corporate strategy, and complementary to strategies of other development partners?

How can ADB ensure the best use of its limited resources to support the DMC?
The CPS narrative may provide opportunities to address disaster risks if it poses a significant challenge to the achievement of sustainable development and poverty reduction objectives.

DRM challenges; ADB's past experience and lessons in implementing DRM assistance, including postdisaster response; and the impact of past disasters on CPS and wider country performance may be taken into account in setting ADB's strategic objectives and priorities, where significant.

The CPS narrative may highlight the level of attention paid to DRM and DRM-related outcomes in the government's development plan, relevant sector plans, and other development partner strategies relative to ADB's proposed engagement, and explain any major divergence.

Where relevant to the sustainability of ADB operations, the CPS may highlight the importance of ensuring the disaster resilience of $A D B$ investments. It may also indicate the value added that ADB can offer in the field of DRM.

$\mathrm{ADB}=$ Asian Development Bank, $\mathrm{CPS}=$ country partnership strategy, $\mathrm{DMC}=$ developing member country, $\mathrm{DRM}=$ disaster risk management.

Source: Adapted from ADB (2016a).

However, the treatment of DRM in a CPS cannot follow any rigid rules. It depends on many factors in a particular country context, including the types of natural hazard faced; the scale and nature of disaster risk, including its distribution of risk over time; government DRM policy, approach, capacity, commitment, and actual practice; the relevance of DRM to ADB's sector and thematic areas of engagement, resources, and country capacity; and the plans and priorities of other development partners. The potential options for addressing DRM in a CPS are the following:

- Include a general reference to DRM needs in the section on ADB's strategy. This will justify relevant program design and investments at any stage of the CPS cycle, including during its implementation through the rolling country operations business plan.

- Treat DRM as a crosscutting concern, informing the strategic outcomes (explicitly or implicitly) of one or more priority sectors that face significant disaster risk, and/or play a significant role in determining levels of disaster risk.

- Treat DRM, or climate and disaster resilience in combination, as a key priority area with a number of associated outcomes in the strategic results framework. This approach is uncommon but could be an option in DMCs that face high disaster risk, especially in small island economies.

CPSs may also routinely identify significant disaster-related risks to the achievement of ADB's development results and include strategies to protect ADB's development objectives against the impact of major natural hazard events. 


\section{E. Monitoring}

To what degree and the manner in which DRM-related outcomes are monitored throughout the CPS process will depend on how they are reflected in the CPS results framework. There are three basic options:

1.) The CPS assessment indicates that a number of priority development outcomes implicitly contribute to strengthened disaster resilience (e.g., via improved access to transport for poor and marginalized communities that increases and diversifies sources of income, thereby strengthening overall resilience to withstand shocks and stresses), with related outcomes or indicators in the results framework reflecting this.

2.) DRM is integrated into a CPS priority area as an explicit key outcome (e.g., flood risk management in the urban infrastructure sector), with a related outcome indicator.

3.) DRM is identified as one of the CPS priority areas, with related intended outcomes and outcome indicators.

Appendix 9 contains examples for these three options and explores specific, measurable, and timebound indicators.

Disaster risk and DRM may also be considered more broadly in CPS evaluations and reviews. The CPS final review and its validation by the Independent Evaluation Department, as well as country assistance program evaluations are considered essential in shaping the directions of new CPSs (ADB 2016b). A CPS final review focuses on the latest CPS period, while a country assistance program evaluation is more indepth, typically covering a period of 7-12 years, which may include two or even three CPS cycles (ADB 2015a). Evaluations look at relevance, effectiveness, efficiency, sustainability, and impact. Even in cases where DRM was not included in the CPS results framework, disaster risk should be reflected upon in the evaluation of CPS performance in countries that have received postdisaster assistance from ADB over the life of the CPS. It is also useful to reflect on disaster risk in medium- and high-disaster-risk countries more generally. Potential questions for consideration include the following:

- Have disasters experienced during the CPS cycle affected CPS objectives or delayed its implementation, either individually or cumulatively?

- Considering the disaster risk profile of the country and ADB's strategic priorities, role, and capacity, did the CPS sufficiently address DRM?

- Could some key projects or the thrust of ADB engagement in particular sectors have benefited by incorporating disaster resilience measures into their design and approach, and/or could they have been steered and managed to contribute more to disaster resilience?

Finally, broader lessons may also be drawn on the impact of actions to integrate DRM into ADB's CPSs and individual projects. This may help strengthen knowledge and understanding of potential obstacles and support the identification of effective practices. Lessons learned-especially in sectors that are particularly relevant in tackling disaster risk such as agriculture, transport, and water-may provide a starting point for further strengthening the safety, welfare, and resilience of poor and vulnerable communities. 


\section{Glossary}

Average annual loss. The expected loss per year calculated or averaged over a long time frame, and expressed as the amount that countries would have to set aside each year to cover the cost of future disasters (UNISDR 2015).

Climate change. A change in the state of the climate that can be identified (e.g., by using statistical tests) by changes in the mean and/or the variability of its properties and that persists for an extended period, typically decades or longer. Climate change may be due to natural internal processes or external forces, or to persistent anthropogenic changes in the composition of the atmosphere or in land use (IPCC 2012).

Climate change adaptation. In human systems, the process of adjustment to actual or expected climate and its effects in order to moderate harm or exploit beneficial opportunities. In natural systems, the process of adjustment to actual climate change and its effects; human intervention may facilitate adjustment to expected climate change (IPCC 2012).

Disaster. Severe alterations in the normal functioning of a community or a society due to hazardous physical events interacting with vulnerable social conditions, leading to widespread adverse human, material, economic, or environmental effects that require immediate emergency response to satisfy critical human needs and that may require external support for recovery (IPCC 2012).

Disaster risk. The potential loss of life, injury, or destroyed or damaged assets which could occur to a system, a society, or a community in a specific period of time, determined probabilistically as a function of hazard, exposure, vulnerability, and capacity (UNISDR 2017).

Disaster risk assessment. A qualitative or quantitative approach to determine the nature and extent of disaster risk by analyzing potential hazards and evaluating existing conditions of exposure and vulnerability that together could harm people, property, services, livelihoods, and the environment on which they depend (UNISDR 2017).

Disaster risk financing. The application of financial instruments as part of a systematic approach to managing disasters in order to anticipate, plan for, reduce, transfer, and respond to natural hazard events. It is intended to capture various financial mechanisms and policy options that enable greater financial resilience to natural hazards (ADB 2013).

Disaster risk management. The application of disaster risk reduction policies and strategies to prevent new disaster risk, reduce existing disaster risk, and manage residual risk, contributing to the strengthening of resilience and reduction of disaster losses (UNISDR 2017).

Disaster risk reduction. Denotes both a policy goal or objective and the strategic and instrumental measures employed for anticipating future disaster risk; reducing existing exposure, hazard, or vulnerability; and improving resilience (IPCC 2012). 
Disaster risk transfer. A contractual process whereby the burden of financial loss (arising as a consequence of a natural hazard) is shifted to another party via the use of insurance or other financing instruments in return for a payment or premium (ADB 2013).

Exposure. The presence of people, livelihoods, environmental services and resources, infrastructure, economic, social, or cultural assets in places that could be adversely affected (IPCC 2012).

Fiscal risk. The likelihood that there will be a shortfall in projected government revenue or additional unforeseen government expenditure requirements, beyond those included in the annual budget. This risk may stem from a range of factors, including natural hazard events (ADB 2013).

Hazard. A pprocess, phenomenon, or human activity that may cause loss of life, injury or other health impacts, property damage, social and economic disruption, or environmental degradation (UNISDR 2017).

Land use planning. The pprocess undertaken by public authorities to identify, evaluate, and decide on different options for the use of land, including consideration of long-term economic, social, and environmental objectives; the implications for different communities and interest groups; and the subsequent formulation and promulgation of plans that describe the permitted or acceptable uses (UNISDR 2009).

Recovery. The restoration or improvement of livelihoods and health, as well as economic, physical, social, cultural, and environmental assets, systems, and activities, of a disaster-affected community or society, aligning with the principles of sustainable development and "build back better," to avoid or reduce future disaster risk (UNISDR 2009).

Residual risk. The disaster risk that remains in unmanaged form, even when effective disaster risk reduction measures are in place, and for which emergency response and recovery capacities must be maintained (UNISDR 2009).

Resilience. The ability of a system, community, or society exposed to hazards to resist, absorb, accommodate, adapt to, transform, and recover from the effects of a hazard in a timely and efficient manner, including through the preservation and restoration of its essential basic structures and functions through risk management (UNISDR 2017).

Vulnerability. The conditions determined by physical, social, economic, and environmental factors or processes which increase the susceptibility of an individual, a community, assets, or systems to the impacts of hazards (UNISDR 2017). 


\section{References}

ADB. 2008. Strategy 2020. The Long-Term Strategic Framework of the Asian Development Bank, 2008- 2020. Manila.

-_- . 2013. Investing in Resilience: Ensuring a Disaster-Resistant Future. Manila.

-- - 2014a. Midterm Review of Strategy 2020: Meeting the Challenges of a Transforming Asia and Pacific. Manila.

_-_. 2014b. Operational Plan for Integrated Disaster Risk Management, 2014-2020. Manila.

-_- . 2015a. Reforming the Country Partnership Strategy. Manila.

- - . 2015b. Report and Recommendation of the President to the Board of Directors: Proposed Results-Based Loan and Technical Assistance Grant to Armenia for the Seismic Safety Improvement Program. Manila.

- - . 2016a. Bank Policies and Operational Procedures. Country Partnership Strategies. Operations Manual. OM A2/BP. Manila.

-_- 2016b. Operations Manual Bank Policies and Operational Procedures. Country Partnership Strategies. Operations Manual. OM A2/OP. Manila.

-_- 2017a. Disaster Risk Assessment for Project Preparation: A Practical Guide. Manila.

- - - 2017b. Natural Hazard Data: A Practical Guide. Manila.

Cabezon, E., L. Hunter, P. Tumbarello, K. Washimi, and Y. Wu. 2015. Enhancing Macroeconomic Resilience to Natural Disasters and Climate Change in the Small States of the Pacific. IMF Working Paper Series. WP/15/125. Washington, DC: International Monetary Fund.

Global Facility for Disaster Reduction and Recovery. 2014. Understanding Risk: The Evolution of Disaster Risk Assessment. Washington, DC.

Intergovernmental Panel on Climate Change (IPCC). 2012. Managing the Risks of Extreme Events and Disasters to Advance Climate Change Adaptation. A Special Report of Working Groups I and II of the Intergovernmental Panel on Climate Change. Cambridge, UK and New York, NY: Cambridge University Press. http://www.ipcc.ch/report/srex/

Taylor, G., K. Vatsa, M. Gurung, and E. Couture. 2013. Review of the Nepal Risk Reduction Consortium. London, New York, and Washington, DC: Humanitarian Outcomes, UNDP, and World Bank.

United Nations (UN). 2015. Sendai Framework for Disaster Risk Reduction 2015-2030. New York.

United Nations International Strategy for Disaster Reduction (UNISDR). 2009. Terminology on Disaster Risk Reduction. http://www.unisdr.org/we/inform/ publications/7817

- - - 2015. Transforming Our World: The 2030 Agenda for Sustainable Development. New York.

- - - 2017. Terminology on DRR. https://www.unisdr.org/we/inform/terminology (accessed 12 March

2017). 


\section{Further Reading}

\section{A. Asian Development Bank (ADB) Policy and Strategy Documents}

ADB. 2004. Disaster Emergency Assistance Policy. Manila.

- - - 2008. Strategy 2020. The Long-Term Strategic Framework of the Asian Development Bank, 20082020. Manila.

- - . 2010. Addressing Climate Change in Asia and the Pacific: Priorities for Action. Manila.

\section{B. ADB Operational Guidelines, Procedures, and Memoranda}

ADB. 2007. Country Partnership Strategies Guidelines. Manila.

- - - 2010. Memorandum on Streamlined Business Processes - Amendments to Board Document Formats and Linked Documents. 20 July. Manila.

-_- 2010. Streamlining Country Partnership Strategies: A Quick Guide. Manila.

_-_. 2012. Environment Safeguards: A Good Practices Sourcebook. Manila.

- - 2012. Handbook on Poverty and Social Analysis. Manila.

-_- 2014. Operational Plan for Integrated Disaster Risk Management, 2014-2020. Manila.

- - . 2014. Tip Sheet: Gender-Inclusive Disaster Risk Management. Manila.

- - . 2015. Reforming the Country Partnership Strategy. Manila.

- - - 2015. Report and Recommendation of the President to the Board of Directors: Proposed Results-Based Loan and Technical Assistance Grant to Armenia for the Seismic Safety Improvement Program. Manila.

-_- 2016. Revised Guidelines for Country Partnership Strategy Results Frameworks. Manila.

- - - 2016. Bank Policies and Operational Procedures. Country Partnership Strategies. Operations Manual. OM A2/BP. Manila.

- - - 2016. Operations Manual Bank Policies and Operational Procedures. Country Partnership Strategies. Operations Manual. OM A2/OP. Manila.

_-_. n.d. Framework for Preparing Sector Assessment, Strategy and Roadmaps in Southeast Asia Regional Department. Manila.

- - V Various dates and documents. E-board entries on country partnership strategies (main paper and linked documents).

\section{Literature on Risk, Disaster Risk Management Capacity Assessments and Indicators}

Food and Agriculture Organization of the United Nations. 2008. Disaster Risk Management Systems Analysis: A Guide Book. Rome.

Global Facility for Disaster Reduction and Recovery. 2014. Understanding Risk: The Evolution of Disaster Risk Assessment. Washington, DC.

Inter-American Development Bank. 2011. Indicators for Risk and Disaster Risk Management.

Programme for Latin America and the Caribbean. Belize.

Intergovernmental Panel on Climate Change. 2012. Managing the Risks of Extreme Events and Disasters to Advance Climate Change Adaptation. A Special Report of Working Groups I and II of the

Intergovernmental Panel on Climate Change. Cambridge, UK and New York, NY: Cambridge University Press. http://www.ipcc.ch/report/srex/

United Nations Development Programme. 2009. Risk Knowledge Fundamentals: Guidelines and Lessons for Establishing and Institutionalizing Disaster Loss Databases. Bangkok.

United Nations International Strategy for Disaster Reduction. 2015. Making Development 
Sustainable: The Future of Disaster Risk Management. Global Assessment Report on Disaster Risk Reduction. Geneva.

World Bank. 2005. Natural Disaster Hotspots: A Global Risk Analysis. Washington, DC.

\section{Literature on Disaster Risk Management Mainstreaming and Resilience}

ADB. 2013a. Investing in Resilience. Ensuring a Disaster-Resistant Future. Manila.

Benson, C., and J. Twigg. 2007. Tools for Mainstreaming Disaster Risk Reduction: Guidance Notes for Development Organizations. Geneva: ProVention Consortium.

Global Facility for Disaster Reduction and Recovery. 2010. Launching a Discussion on Mainstreaming Disaster Risk Reduction into Country Assistance Strategies. Washington, DC.

Inter-American Development Bank. 2014. Climate Change and IDB. Sector Study: Disaster Risk Reduction. Washington, DC.

United Nations Development Group. 2009. Integrating Disaster Risk Reduction into the CCA and UNDAF: Guidance Note for UN Country Teams. New York.

United Nations Development Programme. 2010. Mainstreaming Disaster Risk Reduction into Development at the National Level. Geneva.

\section{E. Literature on Sector-Specific Mainstreaming}

ADB. 2011. Guidelines for Climate Proofing Investment in Transport Sector: Road Infrastructure Projects.

Manila.

- - . 2012. Climate Risk and Adaptation in the Electric Power Sector. Manila.

- - . 2012. Guidelines for Climate Proofing Investment in Agriculture, Rural Development, and Food Security. Manila.

-_- 2013. Flood Risk Management: A Strategic Approach. Manila.

- - . 2013. Guidelines for Climate-Proofing Investments in the Energy Sector. Manila.

- - . 2014. Urban Climate Change Resilience: A Synopsis. Manila.

-_- 2015. Seismic Risk Study of Public Building in the Cities of Dilijan, Gyumri, Jermuk and Vanadzor. Consultant's report. Yerevan.

Asian Disaster Preparedness Center. 2013. Integrating Disaster Risk Management into Urban Management. Disaster Risk Management Practitioner's Handbook Series. Bangkok.

Food and Agriculture Organization of the United Nations. 2014. Mainstreaming Disaster Risk Reduction in Agriculture: An Assessment of Progress Made against the Hyogo Framework of Action (input paper for GAR 2015). Rome.

National Institute of Disaster Management and Deutsche Gesellschaft für Internationale Zusammenarbeit. 2013. Training Module: Critical Infrastructures and Disaster Risk Reduction. New Delhi.

Taylor, G., K. Vatsa, M. Gurung, and E. Couture. 2013. Review of the Nepal Risk Reduction Consortium. London, New York, and Washington, DC: Humanitarian Outcomes, UNDP, and World Bank.

United Nations Environment Programme. 2015. Promoting Ecosystems for Disaster Risk Reduction and Climate Risk Management: Opportunities for Integration. Nairobi.

World Bank. 2012. Resilient Infrastructure for Sustainable Services-Latin America: Mainstreaming of Disaster Risk Management in the Water Supply and Sanitation Sector. Washington, DC

\section{F. General}

Benson, C., and E.J. Clay. 2004. Understanding the Economic and Financial Impacts of Natural Disasters. Washington, DC: World Bank.

Institute of Development Studies. 2010. Assessing Progress on Integrating Disaster Risk Reduction and Climate Change Adaptation into Development Processes. Strengthening Climate Resilience Discussion Paper No. 2. Sussex.

Overseas Development Institute, GFDRR, and World Bank. 2015. Unlocking the Triple Dividend of Resilience: 
Why Investing in Disaster Risk Management Pays Off. London and Washington, DC.

United Nations. 2015. Sendai Framework for Disaster Risk Reduction 2015-2030. New York.

United Nations International Strategy for Disaster Reduction. 2009. Terminology on Disaster Risk Reduction. http://www.unisdr.org/we/inform/ publications/7817

_- - 2015. Transforming Our World: The 2030 Agenda for Sustainable Development. New York.

- - - 2017. Terminology on DRR. https://www.unisdr.org/we/inform/terminology (accessed 12 March 2017).

World Bank and the United Nations. 2010. Natural Hazards, Unnatural Disasters: The Economics of Effective Prevention. Washington, DC. 


\section{Appendix 1: Average Annual Multihazard Losses for ADB Developing Member Countries}

The United Nations International Strategy for Disaster Reduction's Global Assessment Report on Disaster Risk Reduction 2015 presents estimated average annual loss (AAL) data for earthquakes, floods, storm surge, tsunamis, volcano, and wind, and compares the data with a range of social and economic indicators, such as the value of capital stock and annual social expenditure. The following table includes comparisons of AAL relative to gross domestic product as well. A summary sheet for each country can be downloaded from the Global Assessment Report website.' The sheets also report probable maximum loss for mean return periods of $100,250,500,1,000$, and 1,500 years.

\begin{tabular}{|c|c|c|c|c|}
\hline \multirow[b]{2}{*}{ Economy } & \multirow[b]{2}{*}{$\begin{array}{l}\text { Average Annual } \\
\text { Loss ( } \$ \text { million) }\end{array}$} & \multicolumn{3}{|c|}{ Average Annual Loss as \% of: } \\
\hline & & $\begin{array}{l}\text { Capital } \\
\text { Stock }\end{array}$ & $\begin{array}{c}\text { Social } \\
\text { Expenditure }\end{array}$ & $\begin{array}{c}\text { Gross } \\
\text { Domestic } \\
\text { Product }\end{array}$ \\
\hline Afghanistan & 239.0 & 0.8 & 42.5 & 1.2 \\
\hline Armenia & 66.4 & 0.6 & 10.9 & 0.6 \\
\hline Azerbaijan & 326.0 & 0.3 & 8.6 & 0.4 \\
\hline Bangladesh & $3,084.3$ & 1.6 & 96.4 & 2.1 \\
\hline Bhutan & 62.6 & 1.1 & 70.6 & 3.5 \\
\hline Brunei Darussalam & 37.3 & 0.1 & 7.2 & 0.2 \\
\hline Cambodia & 251.2 & 1.8 & 75.0 & 1.6 \\
\hline China, People's Republic of & $31,940.7$ & 0.2 & 7.9 & 0.3 \\
\hline Fiji & 131.8 & 2.3 & 86.5 & 3.4 \\
\hline Georgia & 212.1 & 0.8 & 26.3 & 1.3 \\
\hline Hong Kong, China & $1,138.6$ & 0.2 & 23.7 & 0.4 \\
\hline India & $9,824.9$ & 0.3 & 17.7 & 0.5 \\
\hline Indonesia & $3,575.0$ & 0.5 & 24.3 & 0.4 \\
\hline Kazakhstan & 865.1 & 0.2 & 8.2 & 0.4 \\
\hline Kiribati & 0.0 & 0.0 & 0.1 & 0.0 \\
\hline Kyrgyz Republic & 98.4 & 1.1 & 18.0 & 1.3 \\
\hline $\begin{array}{l}\text { Lao People's Democratic } \\
\text { Republic }\end{array}$ & 224.9 & 2.1 & 89.4 & 2.0 \\
\hline Macau, China & 11.8 & 0.0 & 1.7 & 0.0 \\
\hline Malaysia & $1,287.6$ & 0.2 & 9.2 & 0.4 \\
\hline Maldives & 0.1 & 0.0 & 0.0 & 0.0 \\
\hline Marshall Islands & 0.3 & 0.1 & 0.8 & 0.1 \\
\hline Micronesia, Federated States of & 6.5 & 1.0 & 57.5 & 2.0 \\
\hline Mongolia & 43.2 & 0.2 & 3.1 & 0.3 \\
\hline Myanmar & $2,077.9$ & 2.1 & 0.0 & 3.5 \\
\hline
\end{tabular}

See http://www.preventionweb.net/english/hyogo/gar/2015/en/home/data.php 


\begin{tabular}{|c|c|c|c|c|}
\hline \multirow[b]{2}{*}{ Economy } & \multirow[b]{2}{*}{$\begin{array}{l}\text { Average Annual } \\
\text { Loss ( } \$ \text { million) }\end{array}$} & \multicolumn{3}{|c|}{ Average Annual Loss as \% of: } \\
\hline & & $\begin{array}{l}\text { Capital } \\
\text { Stock }\end{array}$ & $\begin{array}{c}\text { Social } \\
\text { Expenditure }\end{array}$ & $\begin{array}{c}\text { Gross } \\
\text { Domestic } \\
\text { Product }\end{array}$ \\
\hline Nepal & 172.8 & 0.6 & 25.4 & 0.9 \\
\hline Pakistan & $1,327.6$ & 0.5 & 29.4 & 0.6 \\
\hline Palau & 13.0 & 3.3 & 45.7 & 5.7 \\
\hline Papua New Guinea & 169.8 & 0.8 & 19.6 & 1.1 \\
\hline Philippines & $7,892.7$ & 2.9 & 143.1 & 2.9 \\
\hline Samoa & 14.7 & 1.5 & 37.4 & 1.8 \\
\hline Singapore & 2.0 & 0.0 & 0.0 & 0.0 \\
\hline Solomon Islands & 43.4 & 2.4 & 43.7 & 4.1 \\
\hline Sri Lanka & 166.5 & 0.2 & 10.2 & 0.2 \\
\hline Taipei,China & $7,204.0$ & 0.9 & 0.0 & - \\
\hline Tajikistan & 112.7 & 1.1 & 28.4 & 1.3 \\
\hline Thailand & $2,619.4$ & 0.4 & 9.1 & 0.7 \\
\hline Timor-Leste & 15.9 & 0.3 & 14.4 & 1.1 \\
\hline Tonga & 32.7 & 5.0 & 116.7 & 7.5 \\
\hline Turkmenistan & 96.4 & 0.5 & 0.0 & 0.2 \\
\hline \multicolumn{5}{|l|}{ Tuvalu } \\
\hline Uzbekistan & 303.7 & 0.4 & 9.6 & 0.5 \\
\hline Vanuatu & 66.6 & 4.9 & 156.4 & 8.3 \\
\hline Viet Nam & $2,376.1$ & 1.0 & 22.1 & 1.4 \\
\hline
\end{tabular}

Source: United Nations International Strategy for Disaster Reduction. Global Assessment Report on Disaster Risk Reduction 2015 Data. http://www.preventionweb.net/english/hyogo/gar/2015/en/home/data.php 


\section{Appendix 2: Sample Terms of Reference: Disaster Risk Management Country Assessment Specialist}

\section{A. Background}

Strategy 2020 and the 2004 Disaster and Emergency Assistance Policy guide disaster risk management (DRM) at the Asian Development Bank (ADB). Strategy 2020 identifies disaster and emergency assistance as one of ADB's other areas of operations, reflecting the considerable challenge that natural hazards pose to development in Asia and the Pacific. ${ }^{1}$ ADB's Midterm Review of Strategy 2020 reemphasized the importance of strengthened disaster resilience. ${ }^{2}$

ADB's Operational Plan for Integrated Disaster Risk Management, 2014-2020 highlights three key requirements to achieve the vision of disaster resilience: (i) the integration of disaster risk reduction into development; (ii) actions to address the intersection between DRM and climate change adaptation; and (iii) initiatives to ensure that there are adequate financing arrangements in place to reduce risk and to manage and transfer residual risk.

Country partnership strategies (CPSs) articulate ADB's medium-term strategic directions to assist developing member countries to achieve their national development objectives as expressed in their national development plans. In line with Strategy 2020, ADB promotes inclusive and environmentally sustainable growth, and seeks to identify those areas of operations where it can make the most contribution to achieving development impact.

\{Further elaborate upon recent disaster history of the country; impact on the achievement of development goals, broad government approach and level of attention to DRM; and ADB's involvement in DRM, including post-disaster assistance. For instance: "ADB has previously addressed disaster risk in a number of CPSs for \{country name\} and embeds DRM considerations in a wide range of development projects". Or "ADB has not yet addressed disaster risk in CPS but recent disaster episodes with $x x$ losses promoted the need to engage more systematically in DRM in \{country name\}." Briefly explain why ADB considers DRM to be an important factor of promoting inclusive and sustainable development in the country and warrants an assessment to inform country operations. This should include a brief summary of how national development plan(s) have integrated disaster risk concerns.\}

\section{B. Scope of Work}

The DRM country assessment specialist will undertake an assessment of DRM in the country covering:

- disaster risk profile (capturing natural hazards, patterns of exposure, underlying vulnerabilities, and capacities);

- analysis of how these risks may affect a country's key development objectives and sectors and its prospects for inclusive, sustainable, and resilient growth; and

- identification of possible strategic opportunities for ADB to help manage these risks.

$\{$ Adapt above as necessary. For instance, in some countries ADB may choose to focus on DRM in a few key development sectors in line with ADB's project portfolio.\}

ADB. 2008. Strategy 2020: The Long-Term Strategic Framework of the Asian Development Bank, 2008-2020. Manila.

2 ADB. 2014. Midterm Review of Strategy 2020: Meeting the Challenges of a Transforming Asia and Pacific. Manila. 


\section{Detailed Tasks}

The DRM country assessment specialist will do the following:

- Collect and review existing disaster risk assessment information in map, tabular, and other ancillary forms for \{country name\}, as available from:

» global and regional databases and natural hazard or risk assessments,

» national disaster databases,

»natural hazard or risk assessments,

» sector-specific databases and risk assessments, and

»location-specific vulnerability and risk assessments.

- Collect data on recent disasters.

- Collect data on predicted impacts of climate change on natural hazard frequency and intensity.

- Review national development and sector plans and DRM policy, legislation, and programs.

- Review current development partner engagement in DRM.

- Collect and review existing analysis of DRM capacity as available from:

» global and regional DRM capacity assessments and reports, and

»national capacity assessments and reports.

- Undertake consultations with ADB's CPS country team leader, selected ADB officers, and other relevant members of the CPS team.

- Undertake interviews with key informants in ministries of finance and planning, DRM lead agency, selected line agencies, the private sector, civil society organizations, and development partners engaged in DRM.

- Present key findings and conclusions to the CPS team and to key development partners.

- Develop and submit a DRM assessment report.

\section{Output and/or Reporting Requirements}

The specialist will deliver:

- a 20-25-page full DRM assessment report (without appendixes) structured to cover disaster risk profile, risk management capacities, key gaps, and recommendations for ADB based on its comparative advantage in the country; and

- a 2-page summary of the key findings of the report.

The specialist will work under the supervision of \{insert name\}.

\section{E. Expertise}

The specialist should have a postgraduate degree in DRM or a related field, preferably with at least 8 years of national experience in DRM, including in integrating DRM into development planning and processes, and strong writing capability in English. Knowledge of ADB or other multilateral development banks would be an advantage.

\section{F. Places of Assignment}

Consultant's home.

\section{G. Estimated Calendar Days}

25 days intermittent, commencing on \{enter date\} and ending on \{enter date\}. 


\section{Appendix 3: Natural Hazard Data}

Data collected at a global level will provide information on natural hazard occurrence, intensity, and spatial characteristics. The coverage and resolution of the data vary, but low intensity and localized natural hazards are usually not covered. Since the disaster risk management assessment does not aim at conducting original research, the following links are provided merely for cross-checking purposes in case available national data seem unreliable or incomplete.

Please see the companion document, Natural Hazard Data: A Practical Guide, for further details, including a sample national case study (Nepal) listing all national sources of natural hazard data for that country.

\section{Key International and Regional Sources of Hazard Data}

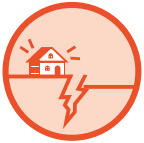

\section{Earthquakes}

https://platform.openquake.org/

http://www.globalquakemodel.org/openquake/about/

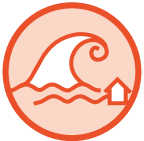

\section{Tsunamis}

https://www.ngdc.noaa.gov/hazard/tsu_db.shtml

$h t t p: / / p t w c . w e a t h e r . g o v /$

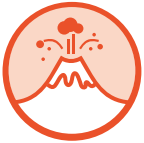

\section{Volcanic eruptions}

http://www.preventionweb.net/english/professional/maps/v.php?id=8773

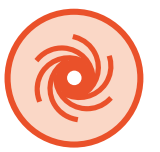

\section{Tropical cyclones}

http://pcrafi.spc.int/

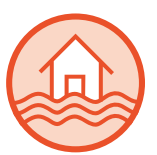

\section{Floods}

http://floodobservatory.colorado.edu/Archives

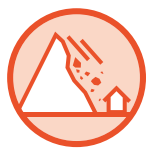

\section{Landslides}

http://preview.grid.unep.ch/index.php?preview=data\&events=landslides\&evcat=1\&lang=eng http://preview.grid.unep.ch/index.php?preview=data\&events=landslides\&evcat=2\&lang=eng

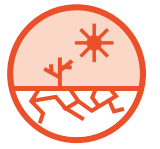

\section{Droughts}

$h t t p: / / p r e v i e w . g r i d . u n e p . c h /$ index.php?preview $=$ data\&events=droughts\&evcat=1\&lang=eng http://drought.eng.uci.edu

\section{Multihazards}

http://risk.preventionweb.net/capraviewer/download.jsp 


\section{National Level}

Natural hazard data and possibly analysis, including hazard mapping products, may be available from a number of national-level research and/or monitoring institutions. These typically include:

- seismological agencies (e.g., earthquakes and collateral landslides, tsunamis);

- geophysical agencies (e.g., earthquakes, volcanic eruptions, land- or mudslides);

- hydrometeorological agencies (e.g., floods, drought, windstorms);

- in some countries, certain sector ministries such as ministries of agriculture, industry, mining or housing that may have data and analytical capacity with regard to flooding/drought, seismic, or landslide hazards; and

- national disaster management agencies that may have multi-hazard information and studies.

\section{Climate Change Projections/Scenarios and Consequences for Natural Hazards}

Sources of analyses on potential changes in extreme weather events as a consequence of climate change include:

- national communications (e.g., http://unfccc.int/national_reports/non-annex_i_natcom/ items/10124.php);

- regional chapters of the Intergovernmental Panel on Climate Change (IPCC) Working Group II contribution to the IPCC's Fifth Assessment Report (http://ipcc.ch/report/ar5/wg2/); and

- IPCC's 2012 special report Managing the Risks of Extreme Events and Disasters to Advance Climate Change Adaptation (http://www.ipcc.ch/report/srex/).

Climate change projections and scenarios are available at the United States National Aeronautics and Space Administration's Earth Exchange Global Daily Downscaled Projections (https://cds.nccs.nasa.gov/ nex-gddp/). 


\section{Appendix 4: Open Spatial Data Sources on Population and Assets}

\section{Population}

http://sedac.ciesin.columbia.edu/data/collection/gpw-v4

Gridded population of the world (grid cell resolution: 2.5 arc-minutes) with a spatially disaggregated population layer covering population estimates for 2000 and projections for 2015.

\section{Building or capital stock}

http://www.nexus.globalquakemodel.org/ged4gem/posts

Building and population inventory using building type classifications with spatial, structural, and occupancy-related information. Suitable for tropical cyclone and earthquake exposure analysis.

\section{Building stock/population/economic}

http://risk.preventionweb.net/capraviewer/main. jsp?tab=7\&mapcenter=13081127.270789,1869368.5554314\&mapzoom=3

A ready-to-use analysis (rather than database) of exposure for the 2015 Global Assessment Report on Disaster Risk Reduction that covers a range of variables, including population, capital stock (disaggregated into urban and rural), and economic indicators.

\section{Agriculture}

http://www.fao.org/gtos/atlas.html

AgroMetShell is a specific software toolbox developed by the Food and Agriculture Organization of the United Nations for crop yield forecasting that facilitates the integration of spatial (map), tabular (spreadsheet), and unstructured (document) data and metadata. It allows data from various sources to be integrated and customized online maps to be produced.

\section{Analytical Overviews of Exposure}

National-level factsheets based on the Global Assessment Report on Disaster Risk Reduction covering a range of indicators can be found at http:/www.preventionweb.net/english/hyogo/gar/2015/en/home/ data.php 


\section{Exposure Data}

Key categories and potential sources of exposure data are the following:

\begin{tabular}{|c|c|c|}
\hline Asset Categories & Explanation & Possible Sources \\
\hline Population & $\begin{array}{l}\text { Demographic numbers and } \\
\text { characteristics (e.g., age, gender, } \\
\text { income) }\end{array}$ & $\begin{array}{l}\text { Census data from statistical } \\
\text { offices }\end{array}$ \\
\hline Capital stock/buildings & $\begin{array}{l}\text { Occupancy types such as residential, } \\
\text { commercial, industrial, administrative, } \\
\text { etc. }\end{array}$ & $\begin{array}{l}\text { Census data (for residential) } \\
\text { Ministries of housing/economy/ } \\
\text { industry } \\
\text { Chambers of commerce }\end{array}$ \\
\hline Agriculture & $\begin{array}{l}\text { Crop production, yield, and acreage; } \\
\text { rainfed and irrigated production; } \\
\text { livestock populations and production; } \\
\text { agricultural assets; land use; land } \\
\text { ownership. }\end{array}$ & Ministries of agriculture \\
\hline Forestry & $\begin{array}{l}\text { Forest types, coverage, and } \\
\text { production }\end{array}$ & Ministries of forestry/environment \\
\hline Fisheries & $\begin{array}{l}\text { Fish farming and commercial fishing } \\
\text { and processing assets }\end{array}$ & Ministries of agriculture/fisheries \\
\hline Transport & $\begin{array}{l}\text { Road, rail, air, water, and other relevant } \\
\text { networks }\end{array}$ & Ministries of transport \\
\hline Lifelines and utilities & $\begin{array}{l}\text { Power generation plants and } \\
\text { transmission and distribution } \\
\text { systems, water supply and distribution } \\
\text { systems, wastewater systems, } \\
\text { telecommunication }\end{array}$ & $\begin{array}{l}\text { Ministries of energy } \\
\text { Ministries of water/natural } \\
\text { resources } \\
\text { Ministries of communication } \\
\text { Urban planning agencies }\end{array}$ \\
\hline $\begin{array}{l}\text { Critical facilities with } \\
\text { high occupancy/losses }\end{array}$ & $\begin{array}{l}\text { Health care facilities, schools and } \\
\text { other educational buildings; public } \\
\text { buildings and offices }\end{array}$ & $\begin{array}{l}\text { Ministries of education/ health/ } \\
\text { public works }\end{array}$ \\
\hline
\end{tabular}

Source: Adapted from Global Facility for Disaster Reduction and Recovery. 2014. Understanding Risk: The Evolution of Disaster Risk Assessment. Washington, DC. 


\section{Appendix 5: Vulnerability Information}

The World Food Programme undertakes food security analysis and monitoring, and provides actionable food security information for each country in which it works. By combining traditional assessment methods with advanced and emerging technologies, the World Food Programme is able to identify foodinsecure populations around the world, and to establish the underlying causes of food insecurity. For further information, see http://www1.wfp.org/food-security-analysis.

Further information on the vulnerability of key sectors such as natural resources and agriculture, and health may be available from government agencies and/or ministries or from international development partners such as the United Nations Development Programme, the World Bank, the World Health Organization, and bilateral agencies.

Vulnerability mapping and analysis at the subnational level are often conducted by the national Red Cross or Red Crescent Society and/or international and local nongovernment organizations, and may provide further qualitative insights into the vulnerability of communities. Typical sources to check include Action Against Hunger, Aga Khan Foundation, International Federation of Red Cross and Red Crescent Societies, Mercy Corps, Oxfam, and Save the Children. 


\section{Appendix 6: Disaster Event and Risk Databases}

Information on losses and damages in past disasters provide important insights into the vulnerability of people and assets. In a growing number of countries, efforts are under way to collect these data in a systematic fashion. Data are also collated and analyzed at a global level.

\section{GLOBAL DATABASES AND INDICES}

Global Assessment Report on Disaster Risk Reduction. Every 2 years, the United Nations Office for Disaster Risk Reduction publishes a major report compiling a review and analysis of data and information on disaster risk patterns and trends, government self-assessments of progress, and an analysis of critical challenges to disaster risk reduction. The Global Assessment Report on Disaster Risk Reduction (GAR) provides global datasets describing hazard, exposure, and risk for many weather and geophysical hazards. Results of the GAR hazard assessment are intended to provide the foundation for global and regional comparison. They are typically too coarse for use in local planning purposes.

Maps and data from the most recent 2015 report can be accessed at http://risk.preventionweb.net/ capraviewer/download.jsp

An overview report of the data and methods included can be found at http://www.preventionweb.net/english/hyogo/gar/2015/en/gar-pdf/Annex1-GAR_Global_Risk_ Assessment_Data_methodology_and_usage.pdf

The GAR 2015 makes its data and maps available free for use in scientific and not-for-profit purposes, with the request for attribution if used in a publication.

EM-DAT International Disasters Database. The EM-DAT International Disasters Database is a global historic catalog containing information on over 18,000 natural and technological events from 1900 to the present. The dataset is maintained by the Centre for Research on the Epidemiology of Disasters at the Université Catholique de Louvain in Brussels, Belgium. For each disaster event, the EM-DAT database stores information on the location, date, loss of human life, people affected, and total damage (expressed in US dollars) as available from various sources, including United Nations agencies, nongovernment organizations, insurance companies, research institutes, and press agencies. The database records disasters that meet at least one of the following criteria:

- 10 or more people reported killed,

- 100 or more people reported affected,

- declaration of a state of emergency, and

- call for international assistance.

Some data, including country profiles, summary tables, graphs, and maps, are available for direct download. Requests for access to full disaggregated data for individual countries, regions, or globally are granted free of charge on a case-by-case basis. It should be noted in analyzing data that entries on total damage are highly incomplete for many developing member countries (DMCs) of the Asian Development Bank (ADB). The EM-DAT database can be accessed at http://www.emdat.be/ 
The World Risk Report. The World Risk Report by the United Nations University Institute for Environment and Human Security is published annually, providing a global index of natural hazard and related disaster risk, and ranking countries accordingly. It is based on available data for the most recent year, providing a ranking of disaster risk specifically in that year. The WorldRisklndex consists of four components: exposure to natural hazards, susceptibility, coping capacity, and adaptive capacity. It is built on 28 individual indicators and covers five natural hazards: earthquakes, cyclones, floods, drought, and sea-level rise. Annual reports and data can be accessed at http://weltrisikobericht.de/english/

Global Climate Risk Index. The Germanwatch annual Global Climate Risk Index analyzes to what extent countries have been affected by the impacts of weather-related loss events over the most recent 20-year period and ranks countries accordingly. The index has an inherent bias related to the relatively short period of analysis, underrepresenting risks associated with low frequency, high-impact events. Annual reports and data can be accessed at https://germanwatch.org/en/cri

\section{REGIONAL DATABASES}

Pacific Catastrophe Risk Assessment and Financing Initiative. The Pacific Catastrophe Risk Assessment and Financing Initiative is a collaboration between the Secretariat of the Pacific Community, ADB, the Government of Japan, and the World Bank. An online platform, the Pacific Risk Information System, hosts over 500 datasets in geographic information system format of national-level hazard and risk information for the 15 countries in participating in the initiative. These include hazard maps for wind and storm surge for 50-, 100-, 250-, and 500-year return periods in raster format at a resolution of roughly 30 meters. Average annual loss and probable maximum loss data were also calibrated under the initiative and are presented in a series of country reports. The data and reports can be accessed at http://pcrafi.spc.int/beta/

\section{NATIONAL DATABASES AND ASSESSMENTS}

DesInventar. The DesInventar Project provides tools and a methodology designed to help governments create and maintain historical disaster impact catalogues, including small localized disasters as well as major events. Losses recorded include human casualties, relocated and evacuated people, damaged and/ or destroyed housing, and losses to infrastructure and vital economic sectors. Information and analyses are presented as maps, charts, databases, and reports. As of August 2016, DesInventar was active in 91 countries around the world, including 24 of ADB's DMCs. More information about DesInventar can be found at http://www.desinventar.org/en/

National historical disaster records. An increasing number of DMCs have specific agencies with responsibility for collating and maintaining databases on historical disaster losses, and related standard methodologies and databases. These records are often maintained by national disaster management agencies. They can include disaggregated data on physical damage by sector, including in physical terms (e.g., length of roads damaged, number of classrooms destroyed). There has been a concerted effort for several years to establish these databases and improve their quality, with support from various development partners including ADB, the United Nations Economic and Social Commission for Asia and the Pacific, and the United Nations Development Programme. 
Multihazard vulnerability and risk assessments. National and subnational multi-hazard vulnerability and risk assessments are increasingly being undertaken in DMCs with the support of international development partners. National disaster management agencies are often involved in these assessments and can provide further information on the availability of assessments.

Quantitative disaster risk assessments. Quantitative disaster risk assessments have been undertaken for some DMCs, often in the context of the development of national disaster risk financing strategies or individual insurance instruments. Outputs are not always in the public domain, however, particularly where they have been developed by proprietary modeling companies. 


\section{Appendix 7: Information on Country Disaster Risk Management Policy, Institutional Arrangements, and Capacity}

Progress reports against international disaster disk management commitments. Most national governments provide biennial reports on their disaster risk management (DRM) arrangements and capacity to the United Nations International Strategy for Disaster Risk Reduction to update their progress on the implementation of international DRM agreements; namely, the Hyogo Framework on Disaster Reduction 2004-2014 and its successor, the Sendai Framework for Disaster Risk Reduction 2015-2030. These reports need to be interpreted with some caution as they are largely qualitative and based on selfreporting. However, they provide overview information on a country's DRM arrangements, orientation, and broad state of progress. National-level reports can be accessed through PreventionWeb at http:// www.preventionweb.net/english/hyogo/progress/reports/

National documents. PreventionWeb collates basic government policy and strategy documents for each country, as well as country DRM-related studies and reports from development partners, potentially including national, subnational, and sector disaster risk assessments. It provides a useful starting point for DRM assessments. Individual country pages can be located via http://www.preventionweb.net/english/ countries/

General and sector-specific information may also be available from national DRM agencies, ministries of planning and finance, relevant sector or line ministries, local governments, and international development partners, including United Nations agencies and the World Bank.

Nationally determined contributions outlining the post-2020 climate actions that countries will take under the international climate agreement at the United Nations Framework Convention on Climate Change Conference of the Parties (COP21) in Paris in December 2015 may contain further information on DRM plans, reflecting the overlap between DRM and climate change adaptation. Nationally determined contributions are available at http://www4.unfccc.int/ndcregistry/Pages/All.aspx 


\section{Appendix 8: Sample Entry Points for Integrating Disaster Risk Management Into Key Sectors}

1. Agriculture and Natural Resources (indicative examples)

\begin{tabular}{|c|c|c|c|}
\hline Core Needs & Policy & Capacity & Investment \\
\hline $\begin{array}{l}\text { Assessing and } \\
\text { monitoring } \\
\text { disaster risk }\end{array}$ & $\begin{array}{l}\text { Integrate DRM into the } \\
\text { agriculture sector plan. } \\
\text { Require the use of risk- } \\
\text { sensitive land use plans/ } \\
\text { risk maps to identify } \\
\text { hazard-prone areas, and } \\
\text { link that information to } \\
\text { agricultural and livelihood } \\
\text { planning. } \\
\text { Establish reporting and } \\
\text { data collection standards } \\
\text { for damage and loss } \\
\text { assessment in the } \\
\text { agriculture sector. }\end{array}$ & $\begin{array}{l}\text { Build capacity of } \\
\text { agricultural extension } \\
\text { workers and staff in the } \\
\text { use of water, weather, and } \\
\text { climate information for } \\
\text { agricultural planning. } \\
\text { Enhance food security } \\
\text { monitoring capacity. }\end{array}$ & $\begin{array}{l}\text { Establish and maintain } \\
\text { disaster damage and } \\
\text { loss databases for the } \\
\text { agriculture sector. } \\
\text { Improve the collection and } \\
\text { dissemination of local and } \\
\text { regional natural hazard } \\
\text { data. } \\
\text { Identify highly exposed } \\
\text { and vulnerable areas and } \\
\text { livelihoods. }\end{array}$ \\
\hline $\begin{array}{l}\text { Reducing } \\
\text { disaster risk }\end{array}$ & $\begin{array}{l}\text { Promote the } \\
\text { development and use of } \\
\text { disaster-resilient food } \\
\text { crops (floods, drought). } \\
\text { Develop livelihood } \\
\text { diversification strategy } \\
\text { for highly exposed and } \\
\text { vulnerable areas. } \\
\text { Ensure women and the } \\
\text { landless are eligible } \\
\text { for training programs } \\
\text { that address livelihood } \\
\text { planning and strategies. }\end{array}$ & $\begin{array}{l}\text { Strengthen community- } \\
\text { based DRM as part of } \\
\text { livelihood programs. } \\
\text { Promote water/soil } \\
\text { conservation and } \\
\text { enhance pastoral risk } \\
\text { management practices. } \\
\text { Provide vocational } \\
\text { training, in particular for } \\
\text { women and youths from } \\
\text { low-income families, } \\
\text { to enhance earnings } \\
\text { and diversify sources of } \\
\text { income. }\end{array}$ & $\begin{array}{l}\text { Invest in DRM programs } \\
\text { that target high-disaster- } \\
\text { risk zones and vulnerable } \\
\text { groups. } \\
\text { Strengthen watershed } \\
\text { management systems in } \\
\text { flood-prone areas. } \\
\text { Increase water storage } \\
\text { through groundwater } \\
\text { recharge, rainwater } \\
\text { harvesting, and } \\
\text { construction of surface } \\
\text { water tanks. } \\
\text { Promote the application } \\
\text { of water-efficient } \\
\text { technologies, such as drip } \\
\text { irrigation. } \\
\text { Promote the construction } \\
\text { of grain storage/silos in } \\
\text { least-risk zones. }\end{array}$ \\
\hline
\end{tabular}




\begin{tabular}{|c|c|c|c|}
\hline Core Needs & Policy & Capacity & Investment \\
\hline $\begin{array}{l}\text { Managing } \\
\text { residual risk }\end{array}$ & $\begin{array}{l}\text { Establish comprehensive } \\
\text { legal and regulatory } \\
\text { framework for agricultural } \\
\text { insurance. } \\
\text { Establish codes and } \\
\text { guidelines for response } \\
\text { and recovery in disasters } \\
\text { impacting agriculture } \\
\text { and food security, } \\
\text { including social protection } \\
\text { mechanisms. }\end{array}$ & $\begin{array}{l}\text { Strengthen financial } \\
\text { literacy regarding } \\
\text { agricultural insurance. } \\
\text { Strengthen awareness } \\
\text { of microcredit and } \\
\text { microinsurance, as well } \\
\text { as social protection } \\
\text { entitlements. } \\
\text { Provide training in first } \\
\text { aid and good hygiene } \\
\text { practices. }\end{array}$ & $\begin{array}{l}\text { Establish public-private } \\
\text { partnerships for agricultural } \\
\text { insurance. } \\
\text { Strengthen social protection } \\
\text { mechanisms for postdisaster } \\
\text { recovery. } \\
\text { Improve seasonal forecasts } \\
\text { and impact-based early } \\
\text { warning systems. }\end{array}$ \\
\hline
\end{tabular}

2. Transport (indicative examples)

\begin{tabular}{|c|c|c|c|}
\hline Core Needs & Policy & Capacity & Investment \\
\hline $\begin{array}{l}\text { Assessing and } \\
\text { monitoring } \\
\text { disaster risk }\end{array}$ & $\begin{array}{l}\text { Require that multihazard } \\
\text { risk assessments inform } \\
\text { the transport master plan } \\
\text { and individual transport } \\
\text { sector projects. } \\
\text { Establish reporting } \\
\text { and data collection } \\
\text { standards on damage and } \\
\text { loss assessment in the } \\
\text { transport sector. }\end{array}$ & $\begin{array}{l}\text { Make disaster risk } \\
\text { information and decision- } \\
\text { making tools (e.g., cost- } \\
\text { benefit analysis) available } \\
\text { to decision makers. } \\
\text { Provide training on } \\
\text { analyzing at-risk transport } \\
\text { assets, GIS mapping, and } \\
\text { scenario building and } \\
\text { interpretation. }\end{array}$ & $\begin{array}{l}\text { Generate data on frequency } \\
\text { intensity, and geographical } \\
\text { distribution of relevant } \\
\text { natural hazards for use } \\
\text { in design and location of } \\
\text { investments. } \\
\text { Make monitoring and } \\
\text { forecast data available for } \\
\text { maintenance scheduling. } \\
\text { Establish and maintain a } \\
\text { disaster damage and loss } \\
\text { database for the transport } \\
\text { sector. }\end{array}$ \\
\hline $\begin{array}{l}\text { Reducing } \\
\text { disaster risk }\end{array}$ & $\begin{array}{l}\text { Integrate natural hazard } \\
\text { and DRM considerations in } \\
\text { sector policies and plans. }\end{array}$ & $\begin{array}{l}\text { Strengthen analytical } \\
\text { and planning capacity } \\
\text { to integrate DRM into } \\
\text { transport planning and } \\
\text { design. }\end{array}$ & $\begin{array}{l}\text { Invest in routine } \\
\text { maintenance of existing road } \\
\text { networks. }\end{array}$ \\
\hline
\end{tabular}




\begin{tabular}{|c|c|c|c|}
\hline Core Needs & Policy & Capacity & Investment \\
\hline $\begin{array}{l}\text { Reducing } \\
\text { disaster risk }\end{array}$ & $\begin{array}{l}\text { Modify and elevate } \\
\text { design and construction } \\
\text { standards for transport } \\
\text { projects in highly hazard- } \\
\text { prone and exposed areas } \\
\text { (taking into account locally } \\
\text { available materials and } \\
\text { common construction } \\
\text { techniques, and reflecting } \\
\text { multihazard environments } \\
\text { where relevant). } \\
\text { Create financial incentives } \\
\text { for a resilient transport } \\
\text { sector. }\end{array}$ & $\begin{array}{l}\text { Train transport sector } \\
\text { staff in applying disaster- } \\
\text { resilient designs and } \\
\text { construction standards, } \\
\text { e.g., for flood-proofing } \\
\text { roads or stronger bridges. } \\
\text { Ensure that contractors } \\
\text { and/or equipment are in } \\
\text { place to detect and address } \\
\text { road routine maintenance } \\
\text { needs promptly. }\end{array}$ & $\begin{array}{l}\text { Reduce exposure and } \\
\text { vulnerability of transport } \\
\text { network through application } \\
\text { of disaster-resilient designs. } \\
\text { Promote bioengineering } \\
\text { and better environmental } \\
\text { management. } \\
\text { Enforce hazard-specific } \\
\text { design, construction, and } \\
\text { maintenance standards. }\end{array}$ \\
\hline $\begin{array}{l}\text { Managing } \\
\text { residual risk }\end{array}$ & $\begin{array}{l}\text { Conduct contingency } \\
\text { planning to identify } \\
\text { critical lifeline transport } \\
\text { infrastructure and } \\
\text { alternative access and } \\
\text { transport options in case of } \\
\text { damage. }\end{array}$ & $\begin{array}{l}\text { Train transport staff and } \\
\text { contractors in emergency } \\
\text { repairs and response. } \\
\text { Ensure the availability and } \\
\text { mobilization of trained } \\
\text { response and emergency } \\
\text { repair teams, especially at } \\
\text { the beginning of the season } \\
\text { for weather-related natural } \\
\text { hazards. }\end{array}$ & $\begin{array}{l}\text { Establish adequate disaster } \\
\text { risk financing instruments to } \\
\text { support timely recovery and } \\
\text { reconstruction. } \\
\text { Invest in upgrading critical } \\
\text { transport infrastructure for } \\
\text { emergency response. }\end{array}$ \\
\hline
\end{tabular}

\section{Energy (indicative examples)}

\begin{tabular}{|c|c|c|c|}
\hline Core Needs & Policy & Capacity & Investment \\
\hline $\begin{array}{l}\text { Assessing and } \\
\text { monitoring } \\
\text { disaster risk }\end{array}$ & $\begin{array}{l}\text { Require that multihazard } \\
\text { risk assessments inform } \\
\text { the energy master plan } \\
\text { and individual energy } \\
\text { sector projects. } \\
\text { Establish reporting and } \\
\text { data collection standards } \\
\text { for damage and loss } \\
\text { assessment in the energy } \\
\text { sector. }\end{array}$ & $\begin{array}{l}\text { Make risk information and } \\
\text { decision-making tools } \\
\text { (e.g., cost-benefit analysis) } \\
\text { available to decision } \\
\text { makers. } \\
\text { Provide training on } \\
\text { analyzing at-risk energy } \\
\text { assets, GIS mapping, and } \\
\text { scenario building and } \\
\text { interpretation. }\end{array}$ & $\begin{array}{l}\text { Generate data on frequency, } \\
\text { intensity, and geographical } \\
\text { distribution of relevant } \\
\text { natural hazards for design of } \\
\text { investments in the energy } \\
\text { sector. } \\
\text { Establish and maintain a } \\
\text { disaster damage and loss } \\
\text { database for the energy } \\
\text { sector. }\end{array}$ \\
\hline
\end{tabular}




\begin{tabular}{|c|c|c|c|}
\hline Core Needs & Policy & Capacity & Investment \\
\hline $\begin{array}{l}\text { Reducing } \\
\text { disaster risk }\end{array}$ & $\begin{array}{l}\text { Promote disaster-resilient } \\
\text { designs and construction } \\
\text { standards for energy } \\
\text { projects in highly hazard- } \\
\text { prone and exposed areas. } \\
\text { Create financial incentives } \\
\text { for a resilient energy } \\
\text { sector. }\end{array}$ & $\begin{array}{l}\text { Strengthen analytical } \\
\text { and planning capacity to } \\
\text { integrate DRM into energy } \\
\text { sector planning and design } \\
\text { of projects. } \\
\text { Train energy sector } \\
\text { staff in disaster-resilient } \\
\text { design and construction } \\
\text { standards and operations. }\end{array}$ & $\begin{array}{l}\text { Enforce risk-sensitive design, } \\
\text { construction, operation, and } \\
\text { maintenance standards. } \\
\text { Invest in increasing } \\
\text { resilience of exposed } \\
\text { or vulnerable energy } \\
\text { infrastructure. }\end{array}$ \\
\hline $\begin{array}{l}\text { Managing } \\
\text { residual risk }\end{array}$ & $\begin{array}{l}\text { Conduct contingency } \\
\text { planning, in particular to } \\
\text { (i) ensure safety of critical } \\
\text { energy infrastructure } \\
\text { affected by natural } \\
\text { hazards; (ii) facilitate } \\
\text { continuity of energy } \\
\text { supply to critical facilities } \\
\text { (e.g., airports, hospitals, } \\
\text { government crisis centers); } \\
\text { and (iii) restore full supply. }\end{array}$ & $\begin{array}{l}\text { Install early warning system } \\
\text { to detect the buildup of } \\
\text { high sediments (damaging } \\
\text { turbines and power plant } \\
\text { installations) and floods. } \\
\text { Ensure that contractors } \\
\text { and/or equipment are in } \\
\text { place to detect and address } \\
\text { damages early on. } \\
\text { Train energy sector } \\
\text { staff and contractors in } \\
\text { emergency repairs and } \\
\text { response. } \\
\text { Ensure the availability and } \\
\text { mobilization of trained } \\
\text { response and emergency } \\
\text { repair teams, especially at } \\
\text { the beginning of the season } \\
\text { for weather-related natural } \\
\text { hazards. }\end{array}$ & $\begin{array}{l}\text { Establish adequate disaster } \\
\text { risk financing instruments to } \\
\text { support timely recovery and } \\
\text { reconstruction. }\end{array}$ \\
\hline
\end{tabular}


4. Water and Other Urban Infrastructure and Services (indicative examples)

\begin{tabular}{|c|c|c|c|}
\hline Core Needs & Policy & Capacity & Investment \\
\hline $\begin{array}{l}\text { Assessing and } \\
\text { monitoring } \\
\text { disaster risk }\end{array}$ & $\begin{array}{l}\text { Require that multihazard } \\
\text { risk assessments inform } \\
\text { urban master and land use } \\
\text { plans. } \\
\text { Establish reporting and } \\
\text { data collection standards } \\
\text { for damage and loss } \\
\text { assessment. }\end{array}$ & $\begin{array}{l}\text { Strengthen the capacity } \\
\text { to use risk assessment } \\
\text { information for urban } \\
\text { planning, including } \\
\text { analyzing at-risk critical } \\
\text { facilities and infrastructure, } \\
\text { GIS mapping, and } \\
\text { interpretation. }\end{array}$ & $\begin{array}{l}\text { Establish urban disaster } \\
\text { damage and loss } \\
\text { database(s). } \\
\text { Invest in the identification } \\
\text { of vulnerability functions for } \\
\text { common building types. } \\
\text { Conduct multihazard risk } \\
\text { assessment of critical urban } \\
\text { infrastructure (such as } \\
\text { water supply and sewerage } \\
\text { system). }\end{array}$ \\
\hline $\begin{array}{l}\text { Reducing } \\
\text { disaster risk }\end{array}$ & $\begin{array}{l}\text { Mandate the use of natural } \\
\text { hazard and exposure } \\
\text { information in the } \\
\text { selection of construction } \\
\text { sites and infrastructure } \\
\text { design. } \\
\text { Strengthen safety codes } \\
\text { and regulations with regard } \\
\text { to urban construction } \\
\text { practices and materials. } \\
\text { Create financial incentives } \\
\text { for the application of } \\
\text { safer construction (see } \\
\text { Investment column). } \\
\text { Clarify land tenure of } \\
\text { and upgrade informal } \\
\text { settlements that are } \\
\text { exposed to medium to high } \\
\text { levels of natural hazard. }\end{array}$ & $\begin{array}{l}\text { Raise capacity of urban } \\
\text { government staff in } \\
\text { enforcing disaster-resilient } \\
\text { housing policies and safety } \\
\text { codes. } \\
\text { Provide training in safer } \\
\text { building techniques to } \\
\text { local builders and masons, } \\
\text { including technical } \\
\text { guidance for self-built } \\
\text { housing schemes. } \\
\text { Raise awareness of } \\
\text { urban dwellers regarding } \\
\text { safety codes and safer } \\
\text { construction practices. } \\
\text { Strengthen DRM awareness } \\
\text { and capacity of community } \\
\text { organizations especially in } \\
\text { informal settlements at risk. }\end{array}$ & $\begin{array}{l}\text { Upgrade urban water } \\
\text { and flood management } \\
\text { infrastructure and systems. } \\
\text { Establish impact-based early } \\
\text { warning systems. } \\
\text { Improve urban waste } \\
\text { disposal systems to prevent } \\
\text { clogging of channels and } \\
\text { drainage. } \\
\text { Retrofit vulnerable critical } \\
\text { facilities such as hospitals } \\
\text { and schools, and strengthen } \\
\text { the resilience of critical } \\
\text { infrastructure. } \\
\text { Observe risk-sensitive } \\
\text { land-use plans, including } \\
\text { by relocating residential } \\
\text { buildings from zones } \\
\text { exposed to high levels } \\
\text { of natural hazard and/or } \\
\text { unacceptable risks. } \\
\text { Provide various economic } \\
\text { incentives for safer } \\
\text { construction or retrofitting } \\
\text { of buildings depending } \\
\text { on target group, e.g., } \\
\text { microfinance, tax relief, } \\
\text { or insurance premium } \\
\text { reductions. }\end{array}$ \\
\hline
\end{tabular}




\begin{tabular}{|c|c|c|c|}
\hline Core Needs & Policy & Capacity & Investment \\
\hline $\begin{array}{l}\text { Managing } \\
\text { residual risk }\end{array}$ & $\begin{array}{l}\text { Establish comprehensive } \\
\text { legal and regulatory } \\
\text { framework for disaster } \\
\text { financing instruments (e.g., } \\
\text { insurance). } \\
\text { Require critical and high- } \\
\text { occupancy facilities (e.g., } \\
\text { hospitals, schools, public } \\
\text { buildings, department } \\
\text { stores) to engage in } \\
\text { emergency planning. }\end{array}$ & $\begin{array}{l}\text { Strengthen financial literacy } \\
\text { regarding disaster risk } \\
\text { financing instruments. } \\
\text { Strengthen urban early } \\
\text { warning system(s). } \\
\text { Promote community- } \\
\text { based first response and } \\
\text { evacuation planning. } \\
\text { Improve the capacity of } \\
\text { urban search and rescue } \\
\text { teams. } \\
\text { Promote exercises and } \\
\text { simulations to improve } \\
\text { response involving relevant } \\
\text { emergency response } \\
\text { agencies. }\end{array}$ & $\begin{array}{l}\text { Promote public- } \\
\text { private partnerships on } \\
\text { property insurance and } \\
\text { microinsurance schemes. } \\
\text { Improve social protection } \\
\text { mechanisms for recovery of } \\
\text { the poor. } \\
\text { Identify and upgrade shelter } \\
\text { facilities in high-risk areas. }\end{array}$ \\
\hline
\end{tabular}

5. Health (indicative examples)

\begin{tabular}{|c|c|c|c|}
\hline Core Needs & Policy & Capacity & Investment \\
\hline $\begin{array}{l}\text { Assessing and } \\
\text { monitoring } \\
\text { disaster risk }\end{array}$ & $\begin{array}{l}\text { Require that multihazard } \\
\text { risk assessments inform } \\
\text { the health master plan and } \\
\text { individual health sector } \\
\text { projects. } \\
\text { Establish reporting and } \\
\text { data collection standards } \\
\text { for damage and loss } \\
\text { assessment in the health } \\
\text { sector. } \\
\text { Assess potential health- } \\
\text { related consequences of } \\
\text { disasters for vulnerable } \\
\text { groups (the elderly, } \\
\text { children, pregnant women, } \\
\text { people with disabilities, } \\
\text { malnourished, etc.). }\end{array}$ & $\begin{array}{l}\text { Strengthen training and } \\
\text { learning interventions on } \\
\text { the capacity to conduct } \\
\text { disaster risk assessments } \\
\text { and postdisaster damage } \\
\text { and needs assessments. }\end{array}$ & $\begin{array}{l}\text { Conduct multihazard risk } \\
\text { assessments of health- } \\
\text { care facilities, including } \\
\text { structural assessments and } \\
\text { assessments of the layout } \\
\text { of facilities, to inform the } \\
\text { development of plans for } \\
\text { continued postdisaster } \\
\text { functioning (e.g., location } \\
\text { of various departments; } \\
\text { positioning of power } \\
\text { generators, dispensaries, } \\
\text { X-ray departments, and } \\
\text { operating theaters). } \\
\text { Assess capacity of health } \\
\text { system to function under } \\
\text { varying disaster scenarios. } \\
\text { Establish and maintain a } \\
\text { disaster damage and loss } \\
\text { database for the health } \\
\text { sector. }\end{array}$ \\
\hline
\end{tabular}




\begin{tabular}{|c|c|c|c|}
\hline Core Needs & Policy & Capacity & Investment \\
\hline $\begin{array}{l}\text { Reducing } \\
\text { disaster risk }\end{array}$ & $\begin{array}{l}\text { Mandate the use of natural } \\
\text { hazard and exposure } \\
\text { information in the } \\
\text { selection of health facility } \\
\text { construction sites and } \\
\text { infrastructure design. } \\
\text { Integrate DRM } \\
\text { considerations into } \\
\text { health-care management } \\
\text { guidelines. }\end{array}$ & $\begin{array}{l}\text { Strengthen analytical } \\
\text { and planning capacity } \\
\text { to integrate DRM into } \\
\text { health sector construction, } \\
\text { management, and delivery } \\
\text { plans. } \\
\text { Make disaster risk } \\
\text { information and decision- } \\
\text { making tools (e.g., cost- } \\
\text { benefit analysis) available } \\
\text { to health-care managers } \\
\text { and decision makers. } \\
\text { Ensure that contractors } \\
\text { are in place to detect } \\
\text { and address road routine } \\
\text { maintenance needs } \\
\text { promptly. }\end{array}$ & $\begin{array}{l}\text { Enforce risk-sensitive } \\
\text { design, construction, } \\
\text { operation, and maintenance } \\
\text { standards. } \\
\text { Retrofit existing health } \\
\text { facilities where relevant. }\end{array}$ \\
\hline $\begin{array}{l}\text { Managing } \\
\text { residual risk }\end{array}$ & $\begin{array}{l}\text { Conduct contingency } \\
\text { planning, in particular to } \\
\text { (i) provide emergency } \\
\text { medical assistance } \\
\text { to disaster-affected } \\
\text { populations, (ii) ensure } \\
\text { continued provision of } \\
\text { essential health services, } \\
\text { (iii) maintain cold chains } \\
\text { for vaccines and other } \\
\text { drugs, and (iv) restore full } \\
\text { delivery of health-care } \\
\text { services. }\end{array}$ & $\begin{array}{l}\text { Ensure the availability } \\
\text { and rapid mobilization } \\
\text { of trained health-care } \\
\text { response teams. } \\
\text { Ensure the availability and } \\
\text { mobilization of health-care } \\
\text { facility emergency repair } \\
\text { teams. }\end{array}$ & $\begin{array}{l}\text { Strategically preposition } \\
\text { emergency drugs and } \\
\text { medical supplies and ensure } \\
\text { sound stock management. } \\
\text { Invest in transport and } \\
\text { other emergency response } \\
\text { equipment. }\end{array}$ \\
\hline
\end{tabular}

DRM = disaster risk management, GIS = geographic information system

Sources: ADB. 2013. Investing in Resilience: Ensuring a Disaster-Resistant Future. Manila; Asian Disaster Preparedness Center. 2013. Integrating Disaster Risk Management into Urban Management. Disaster Risk Management Practitioner's Handbook Series. Bangkok; Food and Agriculture Organization of the United Nations. 2014. Mainstreaming Disaster Risk Reduction in Agriculture: An Assessment of Progress Made against the Hyogo Framework of Action. Rome. 


\section{Appendix 9: Sample Entry Points for Disaster Risk Management in the Country Partnership Strategy Results Framework}

\begin{tabular}{|c|c|c|c|}
\hline $\begin{array}{l}\text { CPS Objectives } \\
\text { aligned with } \\
\text { national } \\
\text { development plans }\end{array}$ & CPS Priority Area & $\begin{array}{l}\text { Key Outcomes that ADB } \\
\text { Contributes to }\end{array}$ & Outcome Indicators \\
\hline $\begin{array}{l}\text { More inclusive } \\
\text { and sustainable } \\
\text { growth }\end{array}$ & $\begin{array}{l}\text { Disaster resilience } \\
\text { (DRM as a priority area) }\end{array}$ & $\begin{array}{l}\text { Government adopts a more } \\
\text { proactive approach to DRM in } \\
\text { its development planning and } \\
\text { budgeting. } \\
\text { Strengthened fiscal capacity to } \\
\text { manage postdisaster response }\end{array}$ & $\begin{array}{l}\text { National development plan, } \\
\text { national investment plan, and } \\
\text { sector strategies integrate } \\
\text { disaster risk considerations } \\
\text { Return period at which } \\
\text { funding gap for postdisaster } \\
\text { response to emergencies is } \\
\text { reduced from 1-in-x to 1-in-y } \\
\text { years. }\end{array}$ \\
\hline \multirow[t]{2}{*}{$\begin{array}{l}\text { More inclusive } \\
\text { and sustainable } \\
\text { growth }\end{array}$} & $\begin{array}{l}\text { Inclusive and sustainable } \\
\text { urban infrastructure }\end{array}$ & $\begin{array}{l}\text { Low-income settlements } \\
\text { in selected cities are more } \\
\text { resilient against floods and } \\
\text { landslides. } \\
\text { (DRM as an explicit outcome } \\
\text { area, among others, which will } \\
\text { be more common) }\end{array}$ & $\begin{array}{l}\text { Number of settlements with } \\
\text { drainage systems increases by } \\
x x \% \text { between } 20 x x \text { and } 20 x x \text {. } \\
\text { Number of newly developed } \\
\text { affordable settlements that } \\
\text { comply with risk-based land } \\
\text { use plans increases by xx\% } \\
\text { between 20xx and 20xx. }\end{array}$ \\
\hline & $\begin{array}{l}\text { Efficient, effective, and } \\
\text { sustainable agricultural } \\
\text { production }\end{array}$ & $\begin{array}{l}\text { Greater resilience of } \\
\text { agricultural production to } \\
\text { climate and disaster risks }\end{array}$ & $\begin{array}{l}\text { Number of farming } \\
\text { households that have access } \\
\text { to crop or livestock insurance } \\
\text { increases by xx\% between } \\
20 x x \text { and } 20 x x \text {. }\end{array}$ \\
\hline $\begin{array}{l}\text { Improved human } \\
\text { capital }\end{array}$ & Human development & $\begin{array}{l}\text { Healthier population } \\
\text { (This outcome will contribute } \\
\text { to DRM but is only implicitly } \\
\text { relevant for DRM. However, } \\
\text { this does not mean that } \\
\text { projects will not include } \\
\text { explicit DRM activities.) }\end{array}$ & $\begin{array}{l}\text { Number of households with } \\
\text { access to reliable, clean } \\
\text { drinking water and sanitation } \\
\text { increases by } x x \% \text { between } \\
20 x x \text { and } 20 x x \text {. }\end{array}$ \\
\hline
\end{tabular}

$\mathrm{ADB}=$ Asian Development Bank, $\mathrm{CPS}=$ country partnership strategy, $\mathrm{DRM}=$ disaster risk management. Source: ADB. 


\section{Disaster Risk Management and Country Partnership Strategies}

A Practical Guide

From 2007 to 2016, disasters triggered by natural hazards caused around 322,000 fatalities, affected 1.7

billion people, and resulted in direct physical damage totaling $\$ 487$ billion in the developing member countries (DMCs) of the Asian Development Bank (ADB) alone.

At the same time, many development actions provide opportunities to strengthen disaster resilience. Integration of disaster risk reduction into development is one of the key principles of ADB's Operational Plan for Integrated Disaster Risk Management. This guide supports the application of this principle by providing technical advice on the integration of disaster risk considerations in ADB country partnership strategy (CPS) preparation. The CPS provides opportunities to initiate a dialogue with DMCs on disaster risk management issues, and to factor disaster risk management considerations into ADB assistance.

\section{About the Asian Development Bank}

ADB's vision is an Asia and Pacific region free of poverty. Its mission is to help its developing member countries reduce poverty and improve the quality of life of their people. Despite the region's many successes, it remains home to a large share of the world's poor. ADB is committed to reducing poverty through inclusive economic growth, environmentally sustainable growth, and regional integration.

Based in Manila, ADB is owned by 67 members, including 48 from the region. Its main instruments for helping its developing member countries are policy dialogue, loans, equity investments, guarantees, grants, and technical assistance. 